\title{
Spontaneously fermented traditional beverages as a source of bioactive compounds: an overview
}

\author{
R. B. Cuvas-Limon ${ }^{\mathrm{a}, \mathrm{b}}$, Clarisse Nobre ${ }^{\mathrm{b}}$ (D), Mario Cruz ${ }^{\mathrm{c}}$, Rosa M. Rodriguez-Jasso ${ }^{\mathrm{a}}$ (D), Héctor A. Ruíz ${ }^{\mathrm{a}}$ (D), \\ Araceli Loredo-Treviño ${ }^{a}$ iD, J. A. Texeirab, and Ruth Belmares ${ }^{a}$ \\ ${ }^{a}$ Food Research Department, School of Chemical Sciences, Autonomous University of Coahuila, Saltillo Coahuila, Saltillo, Coahuila, Mexico; \\ ${ }^{b}$ Centre of Biological Engineering, University of Minho, Braga, Portugal; 'Department of Food Science and Technology, Antonio Narro \\ Autonomous Agricultural University, Saltillo, Coahuila, Mexico
}

\begin{abstract}
Fermented food has been present throughout history, since fermentation not only helps preserving food, but also provides specific organoleptic characteristics typically associated to these foods. Most of the traditional fermented foods and artisanal beverages are produced by spontaneous generation, meaning no control of the microbiota, or the substrate used. Nevertheless, even not being standardized, they are an important source of bioactive compounds, such as antioxidant compounds, bioactive beeps, short chain fatty acids, amino acids, vitamins, and minerals. This review compiles a list of relevant traditional fermented beverages around the world, aiming to detail the fermentation process itself-including source of microorganisms, substrates, produced metabolites and the operational conditions involved. As well as to list the bioactive compounds present in each fermented food, together with their impact in the human health. Traditional fermented beverages from Mexico will be highlighted. These compounds are of high interest for the food, pharmaceutical and cosmetics industry. To scale-up the home fermentation processes, it is necessary to fully understand the microbiology and biochemistry behind these traditional products. The use of good quality raw materials with standardized methodologies and defined microorganisms, may improve and increase the production of the desirable bioactive compounds and open a market for novel functional products.
\end{abstract}

\section{KEYWORDS}

Bioactive compounds; fermentation process Mexican fermented beverages; traditional fermented beverages

\section{Introduction}

In the past, food processing was empirical, but over the years this area has been extensively studied and innovated. Fermentative processes were firstly used by the population to prolong the shelf life of perishable agricultural products. This provided a wide variety of new fermented foods and beverages, that remain nowadays as the main part of the diet of many underdeveloped countries and most Southeast Asian countries (Hugenholtz 2013).

Fermentation is a cost-efficient bioprocess that improves quality, nutritional value and organoleptic properties of many perishable foods (Blandino et al. 2003). Fermented foods are commonly described as foods or beverages processed through controlled microbial growth and enzymatic changes of primary and secondary components of foods (Cifelli et al. 2017). Among the products derived from the most common fermentations marketed worldwide are the fermented alcoholic beverages, such as beer, wine, cider and, particularly in Mexico, tequila, mezcal, pulque, and sotol; and the products derived from fermented milk, such as cheese (a wide variety), yogurt, kefir and, particularly in Mexico, jocoque (Tamang, Shin, et al. 2016).
The fermentation process involves two main factors: the first factor is the type of microorganisms used and the second factor is the substrate. Microorganisms are responsible to initiate the fermentation process of the food, which involves the chemical transformation of primary compounds into new secondary metabolites, that generate organoleptic changes in the product, and thereby, extending the shelf life of the product (Tamang, Watanabe, et al. 2016). These microorganisms can be yeasts, fungi or bacteria (Bourdichon et al. 2012), depending on the substrate to degrade, since the mechanism of the fermentation process varies according to the substrate. The substrates can be meat, fish, dairy, vegetables, cereals, and fruits, including food wastes such as fruit peels (Cifelli et al. 2017).

During the fermentation process, primary and secondary metabolites are produced, such as antibiotics, antimicrobial peptides, carbon dioxide, alcohol, vitamins, folates, and organic acids, that are considered bioactive compounds (Cifelli et al. 2017). Bioactive compounds are molecules with therapeutic potential, that may promote health benefits by decreasing excessive oxidative stress, pro-inflammatory state and metabolism disorders (Siriwardhana et al. 2013). An

CONTACT Ruth Belmares ruthbelmares@uadec.edu.mx E Food Research Department, School of Chemical Sciences, Autonomous University of Coahuila, Saltillo Coahuila, Boulevard Venustiano Carranza e Ing, José Cárdenas s/n Col. República C.P. 25280, Saltillo, Coahuila, Mexico; Clarisse Nobre clarissenobre@gmail.com $\mathbf{E}$ Centre of Biological Engineering, University of Minho, Braga, Portugal.

(C) 2020 Taylor \& Francis Group, LLC 
example are the short chain fatty acids (SCFAs) that reduce and prevent gastrointestinal disorders and colon cancer (Roy et al. 2006; Soret et al. 2010). Currently, the fermentation process is being used to develop emerging food products with health related benefits, the so called functional foods; in addition to their natural properties these new foods can provide extra benefits by helping in the prevention of diseases or strengthening the human body immune system (Siró et al. 2008). Thus, bioactive compounds are a trend as new ingredients in functional foods.

Most food fermentation processes applied around the world are neither standardized nor studied in depth. Nevertheless, final fermented food has been consumed regularly by the population. Thus, the objective of this review is to describe the most relevant traditional fermentative processes used in food modification and preservation. Also, detail as much as possible the process itself and how it affects final food. Food physical and chemical modifications will be detailed, emphasizing the availability of bioactive compounds. Mexican fermented food will be highlighted. The following topics are covered in this review: operational conditions of the fermentation processes, including the microorganisms involved and the substrate source, secondary metabolites generated, bioactive compounds, and health benefits associated to the fermented food.

\section{Factors involved in the fermentation process}

Traditional fermented beverages turned out to be a great source of bioactive compounds. Their matrix constitutes the perfect environment for interactions between substrate and microorganisms involved. Fermentation is a biotransformation process involving two main factors: the starter culture or indigenous microorganisms and the substrate, as well as inherent factors such as the temperature and the $\mathrm{pH}$ conditions (Yunita and Dodd 2018). Nevertheless, traditional fermentations occur generally spontaneously, and operational conditions are not fully controlled, that is, the temperature is usually the room temperature and the initial $\mathrm{pH}$ is dependent on the raw material (food matrix). In spontaneously fermentation, the microorganisms involved are generally a consortia of bacteria, fungi and/or yeasts, which provides the typical sensory characteristics of the products obtained (Smid and Kleerebezem 2014). The type of microorganisms and the substrate have a major role on the sort of products obtained, since primary and secondary metabolites generated are dependent on them. The interaction between these two factors, under controlled conditions, is therefore key to achieve new differentiated products with interesting chemical composition modification and new bioactive substances. Even the fermentations can be classified according to the type of microorganisms used: bacterial, based on yeast or fungi fermentations. Other classification, based in the food nature, divides it into eight groups, such as fermented cereals, vegetables, fruits, legumes, roots/tubers, milk, meat, and fish products (Tamang, Shin, et al. 2016).

\section{First factor: indigenous microorganisms in spontaneously fermented food}

The diversity of the microorganisms initiating the fermentation is directly related to the substrate availability. In food fermentation the presence of microorganisms can be achieved spontaneously or induced. Spontaneous fermentations are based on the presence of microorganisms indigenous to raw materials that exhibit remarkable technological characteristics. However, these microorganisms must have the capacity to grow at high levels, in short time, and act as starter cultures preventing the development of pathogenic bacteria and undesirable decomposition (Holzapfel 2002; Montel et al. 2014; Franciosa et al. 2018; Settanni et al. 2020). Traditional fermented foods and beverages are generally non-standardized products and are based on spontaneous fermentations. In these products indigenous microorganisms are generally a consortia of microorganisms rather than pure cultures (Smid and Lacroix 2013). The consortia may consist in bacteria of different species, for example, lactic acid bacteria (LAB) and acetic acid bacteria $(\mathrm{AAB})$, or a mix of bacteria, fungi, or yeasts. Consortia of microorganisms are more versatile and robust compared to pure cultures, and have even greater resistance against bacteriophages present in the medium (García, Rendueles, and Díaz 2019). However, the coexistence of microorganisms in the same medium reduces growth, adaptation, morphological development and capacity to synthesize proteins and secondary metabolites, since some of the produced metabolites are used as chemical signals for competition communication (Nai and Meyer 2018). The use of microorganism consortia in the artisanal products generally induces a different variety of sensory properties on the same final product (Smid and Kleerebezem 2014).

Currently, scientific research has been focused on improving productivity and underlying pathways by metabolic engineering, or selecting spontaneous or induced mutants (van Hylckama Vlieg et al. 2011). By inducing starter cultures, it has been possible to obtain the same traditional fermented food but with improved organoleptic properties. Several species of microorganisms have been isolated from artisanal fermented products (Sáez, Flomenbaum, and Zárate 2018). Selected species from the isolated ones have been used to induce fermentation. The selection of specific microorganisms as starter cultures allows to improve the quality of the organoleptic properties and eliminates the presence of pathogenic microorganisms (Siroli et al. 2015).

Between the different microorganisms responsible for the fermentation process are the fungi, yeasts, and bacteria. Yeasts such as Saccharomyces cerevisiae are commonly used to produce fermented alcoholic beverages, while LAB have been used mainly in dairy products (Tamang et al. 2015). Between the most common foods that rely on bacterial consortia are cheeses with eyes, where the starter culture are bacterial consortia of $\mathrm{LAB}$ and $\mathrm{AAB}$ (Tamang and Kailasapathy 2010). Fermented beverages such as kefir is another example of food from bacterial consortia. Pulque is an example of an alcoholic fermented beverage based on a 
consortium of microorganisms with bacteria and yeasts (Escalante et al. 2008).

The probiotic properties of many fermented foods are given by the presence of these starter cultures or indigenous microorganisms. Many authors have been reporting that certain yeasts present in fermented food, turn out to have probiotic activity (Tamang et al. 2015; Lu, Putra, and Liu 2018). Bacteria of the lactic acid genus are characterized by providing such benefits by producing bacteriocines and bioactive peptides. For these reasons, the production of bioactive compounds is dependent on the type of microorganisms contained in food, as well as the substrate to be fermented. Microorganisms biotransform the chemical components of the substrates, imparting biopreservative effects and improving the viability of the nutrients. During fermentation, toxic components and anti-nutritional factors are degraded and antimicrobial, antioxidants compounds, peptides, and enzymes are produced. Microorganisms enzymes, in turn, degrade complex compounds into simple ones. The bioactive compounds are promoted by increasing flavonoids and saponins. This process helps to improve sensory quality in food and food safety (Tamang et al. 2009; Farhad, Kailasapathy, and Tamang 2010; Bourdichon et al. 2012; Tamang et al. 2015).

\section{Bacteria}

Among the group of microorganisms initiating fermentation are bacteria. Bacteria can be classified by genus or end products generated, that is, $\mathrm{LAB}$ are responsible for lactic fermentations while $\mathrm{AAB}$ for acetic acid production. In fermented foods and even in spontaneously fermented foods the most isolated microorganisms are the $\mathrm{LAB}$ ones. LAB produce lactic acid as the main final product during sugar fermentation. LAB are gram positive, catalase negative without cytochromes, non-spore forming, non-aerobic or aerotolerant, fastidious, acid-tolerant bacteria (Axelsson 1998). LAB are key in the fermentation process due to their physiological characteristics such as substrate utilization, metabolic capacities and functional properties (Ramos and Schwan 2017). Chemically, LAB are fermenting microorganisms that modify the carbohydrate content of foods, decrease $\mathrm{pH}$ by production of organic acids, synthesize amino acids, improve the availability of B-group vitamins, degrade antinutrients, and increase the availability of some minerals like iron, zinc and calcium (Blandino et al. 2003). By lowering the $\mathrm{pH}, \mathrm{LAB}$ prevent and inhibit the growth of undesirable microorganisms, such as pathogenic microorganisms, rotten and toxicogenic bacteria (Wood and Holzapfel 1995).

$\mathrm{AAB}$ are gram-negative, obligate aerobes, and are classified in the family of the Acetobacteraceae. They are nonspore forming, ellipsoidal to rod-shaped cells that can occur singly, in pairs or in short chains (Malimas et al. 2018; Lynch et al. 2019). The most important genres of AAB used to ferment foods are Acetobacter, Gluconobacter, Gluconacetobacter, and Komagataeibacter (Giudici, De Vero, and Gullo 2017). AAB are characterized by their ability to oxidize carbohydrates, alcohols, and sugar alcohols (polyhydric alcohols or polyols) into their corresponding organic acids, aldehydes, or ketones, in a process designated "oxidative fermentation," which is a source of energy to the cells. Oxidative fermentation is a process of incomplete oxidation of substrates, which are oxidized by primary dehydrogenases of a respiratory chain, with the concomitant release of oxidized products into the surrounding medium (Matsushita and Matsutani 2016; Lynch et al. 2019). Fermented foods are very well-known around the world, a good example is yogurt. Yogurt is probably one of the most studied fermented food over time. It is well-known that the starter cultures of yogurt correspond to a bi-culture of two species, each represented by one strain, the Streptococcus thermophilus and the Lactobacillus delbrueckii subsp. bulgaricus. On the other hand, other foods are characterized by an undefined microbial consortia constituted by multiple eukaryotic and prokaryotic species, such as the case of cheese and bread obtained through sourdough fermentation (van Hylckama Vlieg et al. 2011).

The search in SCOPUS database, for the last 10 years (2009-2019), using the keywords "Isolated of lactic acid bacteria and traditional fermented beverages" yielded 41 documents, being 2016 the year with the highest number of publications (9 articles). Between the traditional fermented beverages are Cauim, Boza, Shalgam, Leben, Pulque, Pozol, Atole agrio, Chal, Chhang, and Bhaati jaanr, that will be following described.

Cauim, also called Kawi, is a beverage produced by Brazilian Indians of the Tapirapé tribe. Cauim is a nonalcoholic beverage produced from diverse substrates like rice, corn, peanut, cotton seed, banana, pumpkin, and cassava (Cíntia et al. 2010). Cassava is used as substrate in many fermented foods widely consumed not only in Brazil, but also in Asia and Africa (Almeida, Rachid, and Schwan 2007). To prepare Cauim, raw materials are cooked for approximately 2 hours and then cooled at room temperature. Further the inoculum is added to the porridge to start the fermentation process (Almeida, Rachid, and Schwan 2007). The species more predominant in Cauim are LAB from the genus Lactobacillus. Ramos et al. (2011) studied the microbial communities involved in the fermentation of a beverage made with cotton seed and rice. They reported 81 yeast and 162 bacteria, 57\% LAB (e.g. Lactobacillus plantarum, Lactobacillus brevis, Lactobacillus paracasei, Leuconostoc lactis, Leuconostoc mesenteroides, Lactococcus lactis), 21\% Bacillus (Bacillus subtilis, Bacillus cereus), $14 \%$ Corynebacterium, and 9\% Enterobacteriaceae. These microorganisms are responsible for chemical and physical changes in food, and to produce antimicrobial substances, creating unfavorable conditions for the growth of pathogens. Furthermore, they play an important role by fermenting carbohydrates such as glucose, maltose, sucrose, and raffinose. It has been reported that Bacillus genus has strong protease and amylolytic activity and provides growth factors like vitamins and soluble nitrogen compounds. Also produces antimicrobial compounds and acids during fermentation which promotes increased security, stability, and shelf life of the final product (Ramos and Schwan 2017). 
Boza, is a traditional fermented beverage consumed in Turkey, Bulgaria, Albania, Romania, South Russia, Fyrom, Anatolia, Middle East an Northern Persia (Arici and Daglioglu 2002; Blandino et al. 2003; Vijaya Kumar, Vijayendra, and Reddy 2015). Boza is based on lactic acid and yeast fermentation of cereals such as millet, maize, wheat, and rice semolina (Panghal et al. 2018). Boza is a viscous drink in the form of a colloidal suspension and pale yellow or light to dark beige. Its characteristic smell is typically acidic-alcoholic, and it holds a slightly acidic or sweet taste (depending on the acid content). The smell and taste are thus, affected by metabolites derived from alcoholic fermentation (Baschali et al. 2017). Boza preparation involves six stages: preparation of raw materials, boiling, cooling, straining, addition of sugar, and fermentation (Arici and Daglioglu 2002). Between the microorganisms identified as indigenous microorganisms of Boza are yeast and $\mathrm{LAB}$ such as Lactobacillus, Lactococcus, Pediococcus, and Leuconostoc (Botes et al. 2007). Specifically, L. plantarum, Lactobacillus acidophilus, Lactobacillus fermentum, Lactobacillus coprophilus, Leuconostoc raffinolactis, $L$. mesenteroides, and Leuconostoc brevis (Baschali et al. 2017). It has been reported that LAB present in this drink produce bacteriocines with probiotic properties. Todorov et al. (2008) reported that $L$. plantarum ST284BZ strain holds antiviral and antibacterial (bacteriocin) capacity being a great probiotic. While L. plantarum ST194BZ has high activity against Mycobacterium tuberculosis which may be used as a bacteriocin to control tuberculosis (Todorov et al. 2008). Busa is other beverage similar to Boza, that uses similar indigenous microorganisms but includes cocoa in the standard Boza recipe. Busa is consumed in the Balkans (Baschali et al. 2017).

Shalgam juice is another traditional Turkish drink, also known as Shalgam. It is originally from the Cukurova province of Turkey but consumed throughout the country. It is made of juice of black or purple carrots (Daucus carota) or turnips (Brassica rapa), sourdough, salt, bulgur (broken wheat) flour, and drinkable water (Erten, Tanguler, and Canbaş 2008). The black carrot, responsible for the red color of the juice, is the main raw material of Shalgam. During fermentation, sugars from the carrot are transformed into lactic acid. Turnip is a minor raw material, as it is added only in amounts up to $2 \%(\mathrm{w} / \mathrm{v})$. Bulgur flour provides nutrients to microorganisms during fermentation. Sourdough is obtained by using yeast dough fermented at room temperature during the night. The added salt is commercial salt or sea salt (Erten, Tanguler, and Canbaş 2008; Tanguler and Erten 2012). The elaboration of Shalgam by the traditional method includes two stages. A first fermentation is carried out to enrich dough with lactic bacteria and yeast, and then, the main fermentation takes place with the carrots (Hasan, Gulden, and Huseyin 2014). Several strains have been identified and isolated from this drink, such as Lactobacillus, Leuconostoc and Pediococcus, specifically $L$. plantarum, L. brevis, L. paracasei, L. acidophilus, Lactobacillus casei, Lactobacillus sanfranciscensis, Lactobacillus pontis, Lactobacillus alimentarius, Lactobacillus fructivorans, Lactobacillus reuteri, and L. fermentum (Erten, Tanguler, and Canbaş 2008; Panghal et al. 2018). The microbiology of Shalgam is complex and not known in detail. Depends on the microorganisms that are present on the surfaces of the raw materials and vessels, where the product is produced and stored, and in the sourdough extract. The fermentation is carried out spontaneously and involves mixed cultures of mainly LAB and yeast (Erten, Tanguler, and Canbaş 2008).

In Tunisia, there is a spontaneously traditional fermented drink called Leben, based on the lactic acid fermentation of milk. Leben is consumed as a fresh drink or as an ingredient of some foods such as a brad couscous (Samet-Bali et al. 2017). Leben is produced with raw milk from cows, goats, ewes, and camels. To prepare Leben, the raw milk is left to ferment spontaneously overnight or more, and then the sour fermented milk is churned in a sac made of goat skin. By churning, the milk is separated into an aqueous fraction the Leben itself, and into a fatty fraction called raw butter (Samet-Bali et al. 2017). The microorganisms responsible for Leben fermentation are LAB predominant, mainly Lactobacillus sp. and Leuconostoc sp., Candida sp., and Saccharomyces sp. (Oyewole 1997). Specifically, Lactococcus lactis subsp. lactis, Streptococcus salivaricus subsp. thermophilus, L. delbrueckii subsp. bulgaricus and yeasts involved in lactic acid fermentations (Candida krusei) (Khedkar, Kalyankar, and Deosarkar 2016). To standardize product characteristics, selected bacterial cultures composed of $L$. lactis species are used to produce an industrial Leben in Tunisia (Samet-Bali et al. 2017). Other traditional beverage from Tunisia is Rayeb that is produced by spontaneous fermentation of milk by LAB. This fermented drink, considered healthy since it helps digestion, has been consumed for centuries. Enterocin $A$, which is a bacteriocin produced by Enterococcus faecium MMRA, was detected in Rayeb (Rehaiem et al. 2010).

Chal is a traditional drink obtained by spontaneous fermentation of camel milk, it is consumed in Turkman Sahra, in Golestan province, Iran. The preparation of Chal consists of mixing fermented camel milk and sour milk previously fermented as inoculum. The mixture is placed in earthenware pots about 1 or 2 days (Soleymanzadeh, Mirdamadi, and Kianirad 2016). Several bacteria have been isolated from Chal such as L. plantarum, Lactobacillus paraplantarum, Lactobacillus kefiri, L. paracasei, L. lactis, Weissella cibaria and E. faecium, Lactobacillus rhamnosus (Fitzgerald and Murray 2006; Hayes et al. 2006).

Chhang is a traditional Indian drink made from cooked rice, and Jau Chhang from cooked barley. Chhang and Jau Chhang are mild alcoholic sweet beverages prepared using traditional inoculum "Phab" in the tribal areas of Himachal Pradesh (Thakur and Chand Bhalla 2004). What is known about Phab is that it is prepared by people from the Nubra valley in the Ladakh region using coarse flour from husked roasted barley (Hordeum vulgare). Artemisia sp. available locally in Ladakh is used to incubate the fresh tablet of Phabs (Angmo and Bhalla 2014). Chhang microbiota is a consortium of different microorganisms that include LAB, 
yeast and molds, such as Pediococcus pentosaceus, L. plantarum, E. faecium, L. casei, Enterococcus lactis, Bacillus amyloliquefaciens, S. cerevisiae, Saccharomyces fibuligera, Candida tropicalis, Pichia kudriavzevii, Serratia proteamaculans, Aspergillus sp., Mucur sp., and Rhizopus sp. (Thakur et al. 2015). Isolates from traditional inoculum of Chhang (Phap and Dheli) are L. plantarum, P. pentosaceus, E. faecium, and S. fibuligera (Thakur and Chand Bhalla 2004).

Pulque is a traditional non-distilled alcoholic fermented beverage of Mexico made from cactus plant (Agave salmiana, Agave atrovireins, and Agave mapisaga) (Tamang, Shin, et al. 2016). It is based on the fermentation of mead that is obtained from agave. The process has four stages: (1) castration, (2) pit scraping and aguamiel (mead) extraction, (3) seed preparation, and (4) fermentation (Escalante et al. 2016). Pulque fermentation is a batch non-stirred process, performed under non-aseptic conditions. It is a spontaneous fermentation, traditionally carried on by the natural microbiota present in the sap (indigenous microorganisms). The fermenting microbiota is based on LAB. The indigenous microorganisms identified in Pulque were L. lactis subsp. lactis, L. plantarum, Lactobacillus acetotolerans, L. acidophilus, Lactobacillus hilgardii, L. kefir, Leuconostoc citreum, Leuconostoc kimchii, L. mesenteroides, Leuconostoc pseudomesenteroides, Zymomonas mobilis, Acetobacter malorum, Acetobacter pomorum, Microbacterium arborescens, Flavobacterium johnsoniae, Gluconobacter oxydans, and Hafnia alvei (Escalante et al. 2008; Escalante et al. 2016; Tamang, Watanabe, et al. 2016).

Pozol is another traditional Mexican drink, consumed in the Mexican southeast, comprising the states of Tabasco, Chiapas, Yucatan, and Campeche. The consumption of Pozol began many years ago by the Mexican Indians, in fact the word Pozol comes from Aztec pozolli. This beverage is a refreshing nonalcoholic drink (Méndez-Albores et al. 2004). The first step to elaborate Pozol is to cook white or yellow maize in $1 \%(\mathrm{w} / \mathrm{v})$ lime solution. The corn can be used alone or mixed with roasted cocoa paste or ground cocoa beans, depending a lot on the region. The second step is to wash it with water and ground it to a mass known as nixtamal. Next step is to mold it into balls in a range from 10 to $12 \mathrm{~cm}$ length and 5 to $8 \mathrm{~cm}$ diameter, which weigh $70-170 \mathrm{~g}$. Balls are wrapped in banana leaves and fermented at room temperature for an average of four days (Nuraida, Wacher, and Owens 1995; Tamang, Shin, et al. 2016). Microorganisms involved in the primary fermentation are mainly LAB, molds and yeasts (Nuraida, Wacher, and Owens 1995). The predominant microorganism isolated were Leuconostoc spp., Streptococcus spp., Enterococcus, Exiguobacterium, Lactobacilli homofermentative, and Lactococci heterofermentative. Different authors have reported microorganisms such as Streptococcus suis, Streptococcus bovis, L. lactis, L. raffinolactis, Lactobacillus confuses, L. fermentum, L. plantarum, L. casei, L. delbrueckii, L. alimentarius, and Bifidobacterium (Wacher et al. 1993; Nuraida, Wacher, and Owens 1995; Wacher et al. 2000; Escalante, Wacher, and Farrés 2001; Díaz-Ruiz et al. 2003).

In the southeastern states of Mexico such as Tabasco, Chiapas and southern Veracruz, Atole Agrio is consumed as a nonalcoholic drink derived from fermented corn. Atole agrio is traditionally prepared by spontaneous fermentation. This beverage can be prepared either by liquid or solid state fermentation. Manufacturing process has only few steps, maize is not boiled nor soaked prior to fermentation, the duration of fermentation is only hours instead of days, and the end product is boiled prior to the consumption (Ampe and Miambi 2000; Castillo-Morales, Wacher-Rodarte, and Hernández-Sánchez 2005). The elaboration process of Atole agrio has been described in detail by (Valderrama 2012; Väkeväinen et al. 2018). Succinctly, first the grains are cut off from the corn cobs with a knifr and grounded and mixed with water to obtain a white dough. For the solid state fermentation, the dough is molded manually into balls of $100 \mathrm{~g}$. Then balls are let to ferment for $12 \mathrm{~h}$ at $34^{\circ} \mathrm{C}$. Finally, it is added $1 \mathrm{~L}$ of water and the maize-water slurry is homogenized by hand. For the liquid fermentation, $750 \mathrm{~g}$ of dough are mixed with $750 \mathrm{~mL}$ of water prior to the fermentation and the slurry is allowed to ferment for $6 \mathrm{~h}$, at $34^{\circ} \mathrm{C}$. The fermentation time were selected based on the traditional manufacturing process of Atole agrio. The suspension is sieved and pasteurized for $10 \mathrm{~min}$ at $100^{\circ} \mathrm{C}$. In case of solid state fermentation there is a slight modification in the process. After the formation of balls, these are fermented 12 hours at $34^{\circ} \mathrm{C}$, and then, the same process is performed. Väkeväinen et al. (2018), identified and characterized LAB of Atole agrio, finding the presence of Enterococcus (5.8\%), Weissella (29.2\%), Pediococcus (24.0\%), Lactococcus (17.8\%), Leuconostoc (6.7\%) and Lactobacillus (16.4\%). Other microorganisms involved in these fermentations are LAB such as L. acidophilus, L. plantarum, L. acetotolerans, L. kefir, L. lactis. subsp. lactis, L. citreum, L. kimchii, L. mesenteroides, an alcohol-producing bacteria (Z. mobilis) (Lappe-Oliveras et al. 2008).

Chorote is other fermented beverage commonly consumed in the South of Mexico, especially in the states of Tabasco, Chiapas, and Oaxaca. It is made from corn and cocoa (Quero 2000). The fermentation of this drink is based on the fermentation with corn dough treated with lime and cocoa beans. Traditionally, the elaboration of the Chorote starts by making balls of approximately $5-10 \mathrm{~cm}$ diameter with the corn dough. Later it is suspended in water like a refreshing drink. The Chorote is a fermentation in solid state, the cocoa beans are roasted and ground and finally add to the corn dough. Isolated microorganisms in Chorote were mainly LAB. The fermentation time takes approximately nine days at room temperature. In Mexico it is considered as popular as Pozol, a drink based on fermented nixtamal (Wacher et al. 1993). In fact, Chorote, Pozol and sour Atole agrio are very similar traditional drinks. Table 1 shows some traditional fermented beverages consumed in different parts of the world, including the substrate used, the microorganisms involved in the fermentations, which are generally consortia of bacteria and yeasts, and the metabolites produced in these fermentations.

\section{Yeasts and molds}

Yeasts are defined as unicellular ascomycetous or basidiomycetous fungi (Kurtzman, Fell, and Boekhout 2011; Lambrechts and Pretorius 2019). Yeast monocultures are 


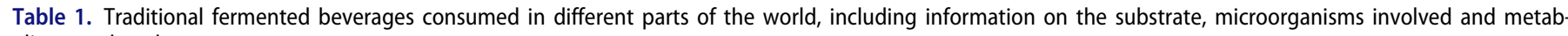
olites produced.

\begin{tabular}{|c|c|c|c|c|c|}
\hline \multirow[b]{2}{*}{ Product } & \multirow[b]{2}{*}{ Substrate } & \multicolumn{2}{|c|}{ Microorganism } & \multirow[b]{2}{*}{ Metabolites } & \multirow[b]{2}{*}{ Reference } \\
\hline & & Bacteria & Yeast & & \\
\hline Boza & $\begin{array}{l}\text { Cereals like bulgur, } \\
\text { maize, chickpea, } \\
\text { millet, wheat, or rice }\end{array}$ & $\begin{array}{l}\text { Lactobacillus plantarum, } \\
\text { Lactobacillus fermentum, } \\
\text { Lactobacillus sanfranciscensis, } \\
\text { Lactobacillus coryniformis, } \\
\text { Lactobacillus confuses, } \\
\text { Leuconostoc } \\
\text { paramesenteroides, } \\
\text { Leuconostoc mesenteroides, } \\
\text { Lactobacillus brevis. }\end{array}$ & $\begin{array}{l}\text { Saccharomyces uvarum, } \\
\text { Saccharomyces cerevisiae }\end{array}$ & $\begin{array}{l}\text { Lactic acid, ethanol plus } \\
\text { esters, lipid, protein, } \\
\text { vitamin B, amino acids, } \\
\text { phenolic acid, ferulic acid, } \\
\text { vanillic acid, protocatechuic } \\
\text { acid, y-oryzanol, phytic } \\
\text { acid, and inositol. }\end{array}$ & $\begin{array}{l}\text { Blandino et al. (2003); } \\
\text { Dogan and } \\
\text { Ozpinar (2017) }\end{array}$ \\
\hline Turnip juice & Black carrots & $\begin{array}{l}\text { Enterococcus faecalis, } \\
\text { Lactobacillus bavaricus, } \\
\text { L. brevis, } \\
\text { L. plantarum, } \\
\text { Lactococcus lactis, } \\
\text { L. mesenteroides, } \\
\text { Pediococcus pentosaceus. }\end{array}$ & & $\begin{array}{l}\text { Acetic acid, lactic acid, } \\
\text { propionic acid, ammonia, } \\
\text { amines, aldehydes, } \\
\text { phenols, indole, alcohols, } \\
\text { amino acids (cysteine, } \\
\text { methionine). }\end{array}$ & $\begin{array}{l}\text { Wu and Li (2018); Erten, } \\
\text { Tanguler, and } \\
\text { Canbaş (2008) }\end{array}$ \\
\hline Leben & Milk & $\begin{array}{l}\text { L. lactis, } \\
\text { L. mesenteroides. }\end{array}$ & $\begin{array}{l}\text { Candida sp., } \\
\text { Saccharomyces sp. }\end{array}$ & $\begin{array}{l}\text { Acetic acid, lactic acid, } \\
\text { propionic acid, malic acid, } \\
\text { formic acid, bacteriocins, } \\
\text { antimicrobial peptides, } \\
\text { phenolic acids, ferulic acid, } \\
\text { antioxidants compounds, } \\
\text { aromatic compounds, } \\
\text { organic and fatty acid. }\end{array}$ & $\begin{array}{l}\text { Odunfa and Oyewole } \\
\text { (1998); Holzapfel and } \\
\text { Schillinger (2002); } \\
\text { Even et al. (2010); } \\
\text { Ramos et al. (2011) }\end{array}$ \\
\hline Chhang & Rice & $\begin{array}{l}\text { L. plantarum, } \\
\text { Lactobacillus. }\end{array}$ & & $\begin{array}{l}\text { Acetic acid, lactic acid, } \\
\text { propionic acid, malic, acid, } \\
\text { formic acid, bacteriocins, } \\
\text { antimicrobial peptides, } \\
\text { phenolic acids, ferulic acid. }\end{array}$ & $\begin{array}{l}\text { Handa and Sharma } \\
\qquad(2016)\end{array}$ \\
\hline Sundug & Black Grape wine & $\begin{array}{l}\text { Lactobacillus, } \\
\text { Streptococcae, } \\
\text { Oenococcus, } \\
\text { Pediococcus sp. }\end{array}$ & $\begin{array}{l}\text { S. cerevisiae, } \\
\text { Kloeckera, Hanseniaspora, } \\
\text { Candida, } \\
\text { Pichia, } \\
\text { Metschnikowia, Torulaspora, } \\
\text { Kluyveromyces, } \\
\text { Schizosacchaomyces, } \\
\text { Zygosaccharomyces, } \\
\text { Brettanomyces }\end{array}$ & $\begin{array}{l}\text { Ethanol, phenolic compounds, } \\
\text { anthocyanins, } \\
\text { hydroxybenzoic acid, } \\
\text { hydroxycinnamic acid, } \\
\text { flavonoids. }\end{array}$ & $\begin{array}{l}\text { Ribéreau-Gayon (2000); } \\
\text { Tamang, Watanabe, } \\
\text { et al. (2016) }\end{array}$ \\
\hline Pozol & Corn & $\begin{array}{l}\text { Leuconostoc sp., } \\
\text { Heterofermentative, } \\
\text { Lactobacillus sp., } \\
\text { Homofermentative. }\end{array}$ & $\begin{array}{l}\text { Candida sp., } \\
\text { Trichosporon cutaneum. }\end{array}$ & $\begin{array}{l}\text { Folate, phytic acid, acetic } \\
\text { acid, lactic acid, succinic } \\
\text { acid, esters, higher } \\
\text { alcohols, glycerol, } \\
\text { acetaldehyde. }\end{array}$ & $\begin{array}{l}\text { Nuraida, Wacher, and } \\
\text { Owens (1995); } \\
\text { Väkeväinen et al. } \\
\text { (2018) }\end{array}$ \\
\hline Pulque & $\begin{array}{l}\text { Agave } \\
\text { Aguamiel }\end{array}$ & $\begin{array}{l}\text { Lactobacillus acidophilus, } \\
\text { L. mesenteroides, } \\
\text { Acetobacter } \\
\text { pomorium,Gluconobacter } \\
\text { oxydans. }\end{array}$ & $\begin{array}{l}\text { S. cerevisiae, } \\
\text { Zymomonas mobilis. }\end{array}$ & $\begin{array}{l}\text { Oxalic, saccharic, keto- } \\
\text { glucconic, vitamins, and } \\
\text { hydrolytic enzymes, } \\
\text { ethanol, minerals, organic } \\
\text { acids, and phytates. }\end{array}$ & $\begin{array}{l}\text { Escalante et al. (2004); } \\
\text { Correa-Ascencio et al. } \\
\text { (2014); Escalante } \\
\text { et al. (2016); De Roos } \\
\text { and De Vuyst (2018) }\end{array}$ \\
\hline Tejuino & Corn dough & $\begin{array}{l}\text { L. acidophilus, } \\
\text { L. mesenteroides. }\end{array}$ & & $\begin{array}{l}\text { Mannitol, fructose, } \\
\text { antimicrobial peptides, } \\
\text { organic acids, amino acids. }\end{array}$ & Freire et al. (2017) \\
\hline Kefir & Milk and Kefir grains & $\begin{array}{l}\text { Lactobacillus, } \\
\text { Lactococcus, } \\
\text { Leuconostoc, } \\
\text { Acetobacter. }\end{array}$ & $\begin{array}{l}\text { Kluyveromyces marxianus } \\
\quad \text { subsp. lactis, } \\
\text { S. cerevisiae, } \\
\text { Candida inconspicua, } \\
\text { Candida maris. }\end{array}$ & $\begin{array}{l}\text { Antimicrobial peptides, amino } \\
\text { acids, acetic acid, lactic } \\
\text { acid, and other organic } \\
\text { acids and vitamins (folic } \\
\text { acid, riboflavin, cobalamin) }\end{array}$ & $\begin{array}{l}\text { Güzel-Seydim et al. } \\
\text { (2000); Simova et al. } \\
\text { (2002); Wu and Li } \\
\text { (2018) }\end{array}$ \\
\hline Kimchi & Meat, fish and cabbage & $\begin{array}{l}\text { Alkalibacterium, } \\
\text { L. mesenteroides, } \\
\text { Weissella. }\end{array}$ & $\begin{array}{l}\text { Halococcus spp., } \\
\text { Natronococcus spp., } \\
\text { Natrialba spp., } \\
\text { Haloterrigena spp., } \\
\text { Lodderomyces spp., } \\
\text { Trichosporon spp., Candida } \\
\text { spp., Saccharomyces spp., } \\
\text { Pichia spp., } \\
\text { Sporisorium spp., } \\
\text { Kluyveromyces spp. }\end{array}$ & $\begin{array}{l}\text { Antimicrobial peptides, amino } \\
\text { acids, propionic acid, } \\
\text { carbon dioxide, hydrogen } \\
\text { peroxide, bacteriocins, } \\
\text { antifungical peptides. }\end{array}$ & $\begin{array}{l}\text { Collins et al. (1993); } \\
\text { Chang et al. (2008); } \\
\text { Wu and Li (2018) }\end{array}$ \\
\hline Wine, beer & Grapes, barley & & & & \\
\hline
\end{tabular}


Table 1. Continued.

\begin{tabular}{|c|c|c|c|c|c|}
\hline \multirow[b]{2}{*}{ Product } & \multirow[b]{2}{*}{ Substrate } & \multicolumn{2}{|c|}{ Microorganism } & \multirow[b]{2}{*}{ Metabolites } & \multirow[b]{2}{*}{ Reference } \\
\hline & & Bacteria & Yeast & & \\
\hline & & $\begin{array}{l}\text { Lactobacillus, } \\
\text { Streptococcus, } \\
\text { Pediococcus. }\end{array}$ & $\begin{array}{l}\text { S. cerevisiae, Saccharomyces } \\
\quad \text { unisporus, } \\
\text { Candida pelliculosa, Candida } \\
\text { glabrata, Candida sake, } \\
\text { Candida guilliermondii. }\end{array}$ & $\begin{array}{l}\text { Alcohol. carbon dioxide, } \\
\text { ethanol, gluconic acid, } \\
\text { ethyl gluconate, phenolic } \\
\text { compounds, tyrosol, } \\
\text { hydroxytyrosol, tryptophol, } \\
\text { glutathione, cysteine, } \\
\text { glycine, melatonin, } \\
\text { tryptophan, caffeic acid, } \\
\text { folates, sterols, lignans, free } \\
\text { ferulic acids and } \\
\text { alkylresorcinols. }\end{array}$ & $\begin{array}{l}\text { Velićanski et al. (2014); } \\
\text { Petruzzi et al. (2016); } \\
\text { Vilela (2019) }\end{array}$ \\
\hline Kombucha & Fungus or mushroom & $\begin{array}{l}\text { Acetobacter xylinum, } \\
\text { Acetobacter xylinoides, } \\
\text { Bacterium gluconicum. }\end{array}$ & $\begin{array}{l}\text { Saccharomyces spp., Torulopsis } \\
\quad \text { spp., } \\
\text { Pichia spp., Brettanomyces } \\
\text { spp., Zygosaccharo } \\
\text { myceskombuchaensis. }\end{array}$ & $\begin{array}{l}\text { Sugars, ethyl gluconate, } \\
\text { oxalic, lactic, keto- gluconic } \\
\text { and amino acids, vitamins, } \\
\text { tea components (catekhins, } \\
\text { flavonols) hydrolytic } \\
\text { enzymes, acetaldehyde, } \\
\text { acetic acid, succinic acids, } \\
\text { glycerol, terpenoids, esters. }\end{array}$ & $\begin{array}{l}\text { Tamang and Fleet } \\
\text { (2009); Velićanski } \\
\text { et al. (2014); Petruzzi } \\
\text { et al. (2016) }\end{array}$ \\
\hline Bhaati jaanr & Rice & $\begin{array}{l}\text { P. pentosaceus, } \\
\text { Lactobacillus bifermentans. }\end{array}$ & $\begin{array}{l}\text { Saccharomyces fibuligera, } \\
\text { Pichia anomala, } \\
\text { S. cerevisiae, } \\
\text { C. glabrata. }\end{array}$ & $\begin{array}{l}\text { Phenolic compounds, } \\
\text { flavonoids, coumarins, } \\
\text { lignans, tannins, terpenes, } \\
\text { tocopherols, phospholipids, } \\
\text { aldehydes, ketones and } \\
\text { ply-functional organic } \\
\text { acids, volatiles compounds, } \\
\text { ethyl esters and fatty acids. }\end{array}$ & $\begin{array}{l}\text { Tamang and } \\
\text { Thapa (2006) }\end{array}$ \\
\hline $\begin{array}{l}\text { Alcoholic } \\
\text { beverages } \\
\text { and non- } \\
\text { food } \\
\text { mixed } \\
\text { amylolytic } \\
\text { astarter }\end{array}$ & $\begin{array}{l}\text { Fruits, cereals } \\
\text { and vegetables }\end{array}$ & $\begin{array}{l}\text { Lactobacillus, } \\
\text { Streptococcus, } \\
\text { Pediococcus. }\end{array}$ & $\begin{array}{l}\text { Brettamomyces intermedius, } \\
\text { Candida lodderae, } \\
\text { Debarymyces dekkera, } \\
\text { Kluyveromyces delphensis, } \\
\text { S. cerevisiae, } \\
\text { S. fibuligera, } \\
\text { Zygosaccharomyces. }\end{array}$ & $\begin{array}{l}\text { Antibiotics, antimicrobial } \\
\text { compounds, antimicrobial } \\
\text { peptides, amino acids, } \\
\text { ribosomal peptides, } \\
\text { bacteriocins (I, II, II), } \\
\text { enzymes and polyketides } \\
\text { (acetogenins, ansamycins, } \\
\text { enediynes, macrolids, } \\
\text { polynes, polythers, } \\
\text { tetracycline), fatty acids } \\
\text { and derivates (benzenoids, } \\
\text { furans, esters, alcohols, } \\
\text { aldehydes, alkanes), volatile } \\
\text { compounds (nitrogen- } \\
\text { containing volatile organic } \\
\text { compounds, terpenoids, } \\
\text { sulphur- containing), } \\
\text { lipopeptides (fegycins, } \\
\text { iturins, surfactins, kurtakins) }\end{array}$ & $\begin{array}{l}\text { Tamang and Fleet } \\
\text { (2009); Petruzzi et al. } \\
\text { (2016); Caulier et al. } \\
\text { (2019); Vilela (2019) }\end{array}$ \\
\hline Cheese & Milk & $\begin{array}{l}\text { Lactobacillus, } \\
\text { Lactococcus, } \\
\text { Enterococcus, } \\
\text { Leuconostoc. }\end{array}$ & $\begin{array}{l}\text { Bifidobacterium, } \\
\text { Brachybacterium, } \\
\text { Brevibacterium, } \\
\text { Propionibacterium. }\end{array}$ & $\begin{array}{l}\text { Organic acid, aromatic } \\
\text { compounds, fatty acids, } \\
\text { sensorial properties. }\end{array}$ & $\begin{array}{l}\text { Falchero et al. (2010); } \\
\text { Bourdichon } \\
\text { et al. (2012) }\end{array}$ \\
\hline
\end{tabular}

frequently used to create fermented alcoholic and nonalcoholic beverages and foods, such as cheeses, breads, and other products (Hittinger, Steele, and Ryder 2018).

Yeast play an important role during fermentation, since they are responsible for the production of organic acids and alcohol, providing flavor, texture and aroma to fermented foods. However, the organoleptic properties provided depend on nutritional content and toxin-reducing factors (Rai and Jeyaram 2017). For example, fermentation of cereal by yeast promotes high levels of total sugars, sterols, lignans, free ferulic acids, and alkylresorcinols, as well as total phenolic content and aroma formation (Vieria-Dalodé et al. 2008; Yeo and Ewe 2015).

The most common yeast in fermented food is $S$. cerevisiae. Nevertheless, many other yeasts have been isolated from traditional fermented foods and non-food mixed amylolytic starters, such as: Brettanomyces anomalus, Candida javanica, Geotrichum candidum, Hansenula anómala, Pichia burtonii, Rhodotorula glutinis, Saccharomycopsis fibuligera, S. cerevisiae, Saccharomyces dairensis, Saccharomyces globosus, Saccharomyces kluyveri, Saccharomyces saké, Torulopsis versatilis, Trichosporon pullulans, Zygosaccharomyces rouxii (Tamang and Fleet 2009; Table 1).

In spontaneously fermented foods, yeasts have been identified as indigenous microorganisms that initiate the fermentation process, such as in Kombucha, Shalgam, Leben, Boza, Bhaati jaanr, Chhang, Pozol and Atole agrio, which will be further detailed.

Kombucha is a traditional fermented beverage, based on a consortium of $\mathrm{AAB}$ and yeasts. Yeasts that have been isolated from Kombucha are Brettanomyces bruxellensis, 
Candida stellada, Schizosaccharomyces pombe, Torulaspora delbrueckii, and Zygosaccharomyces baili. In fermentation of Shalgam S. cerevisiae is used (Hasan, Gulden, and Huseyin 2014). Samet-Bali et al. (2017), isolated Candida lusitanie, C. tropicalis and C. krusei from Leben fermentation. An amount of $4.61 \pm 0.21 \log$ count $\left(\log _{10} \mathrm{CFU} / \mathrm{mL}\right)$ of yeasts and molds were determined in Leben.

Boza is produced by simultaneous fermentation with bacteria and yeast. Yeasts are responsible for the alcoholic fermentation, producing carbon dioxide bubbles and increasing the volume, while bacteria produces lactic acid and gives the acidic character to Boza in the lactic acid fermentation. Yeasts isolated and identified from Boza were Saccharomyces carlsbergensis, S. cerevisiae, Saccharomyces uvarum (Arici and Daglioglu 2002) and, C. tropicalis, Candida glabrata, Geotrichum penicillum and G. candidum (Baschali et al. 2017).

Bhaati jaanr is a traditional fermented rice paste. It is commonly consumed as a mild-alcoholic sweet-beverage in the rural areas of the Darjeeling hills, Sikkim and Northeast in India, Nepal and Bhutan. To produce Bhaati jaanr, glutinous rice is cooked for about $15 \mathrm{~min}$ in an open cooker, excess water is drained off, and cooked rice is spread on a bamboo mat for cooling. A dry mixed starter culture called marcha is powdered, and about $2 \%$ of it is sprinkled over the cooked rice, mixed well and kept in a vessel or an earthen pot for 1-2 days at room temperature for saccharification. Filamentous molds identified in Bhaati jaanr, were Mucor circinelloides, Rhizopus chinensis, and Rhizopus stolonifera. Yeasts identified were S. fibuligera, Pichia anomala, S. cerevisiae, and C. glabrata (Tamang and Thapa 2006). Rhizopus strains play an important role in the saccharification process of rice. Tamang and Thapa (2006) reported the physicochemical changes occurring during fermentation of Bhaati jaanr, such as $\mathrm{pH}(3.5)$, acidity (0.24\%), moisture (83.4\%), and alcohol $(5.9 \%)$ during fermentation. Yeasts increased significantly $(p<0.05)$ from $10^{5}$ to $10^{8} \mathrm{CFU} \mathrm{g}^{-1}$ on day 2 and decreased to a level of $10^{5} \mathrm{CFU} \mathrm{g} \mathrm{g}^{-1}$ on day 10 .

Yeasts isolated in Chhang and Jau Chhangbeverages, which fermentation process was described in the previous section, and Sura were S. cerevisiae, S. fibuligera, C. tropicalis, and P. kudriavzevii (Thakur et al. 2015). Molds and fungi as Bacillus are usually employed for starch saccharification or proteolysis, or as secondary ripening microbiota after a primary fermentation (Cifelli et al. 2017). It has been reported that species of Bacillus have been isolated from fermented foods based on legumes.

Between the yeasts detected during Pulque fermentation are Saccharomyces and other yeast, which during the fermentative process produce ethanol, amino acids, vitamins, and volatile flavor compounds (Lappe-Oliveras et al. 2008). The microbial diversity of Pulque includes Saccharomyces cerevisiae subsp. chevalieri, Saccharomyces cerevisiae subsp. capensis, Saccharomyces bayanus, Saccharomyces pastorianus, Kluyveromyces marxianus, Kluyveromyces lactis, Candida valida, Candida parapsilosis, Clavispora lusitaniae, Debaryomices carsonii, Hanseniaspora uvarum, G. candidum, Pichia guilliermondii, Pichia membranifaciens, Rhodotorula mucilaginosa (Escalante et al. 2016).
Yeasts involved in Pozol fermentations are a diversity of species of the genus Candida and filamentous yeast such as Trichosporon cutaneum and G. candidum (Nuraida, Wacher, and Owens 1995). Others species identified are Rhodotorula minuta, R. mucilaginosa, Debaryomyces hansenii, Candida guilliermondii subsp. guilliermondii, Kluyveromyces lactis subsp. lactis, Clodosporium cladosporioides, Phoma glomerata, Phoma fimeti, G. candidum, Penicillum fellutanum (Wacher et al. 2000).

The yeasts involved in Atole agrio are mainly Saccharomyces, the most common is the $S$. cerevisiae. Other yeasts found were Candida spp. and C. lusitaniae (Cervantes Contreras and Pedroza Rodríguez 2007; Lappe-Oliveras et al. 2008).

\section{Second factor: substrate}

Fermentation can occur as a natural and spontaneous phenomenon as long as there is a raw material (substrate) available, either animal or vegetable, and a microorganism consortium naturally present in the substrates to begin fermentation activity (Septembre-Malaterre, Remize, and Poucheret 2018).

The type of by-products that are obtained, as well as the development of textures, flavors and odors depends on the substrate and microorganisms involved. The substrate must have a rich chemical composition, including high concentrations of mono and di-saccharides and the minerals necessary to start the microbial metabolism. But at the same time, it must not contain inhibitors such as toxins that inhibit the growth of these microorganisms. It is true that environmental conditions influence the fermentation process, but traditional fermented foods are not standardized processes, which means that these conditions are not always the same. Microorganisms usually grow at room temperature $\left(25-27^{\circ} \mathrm{C}\right)$ and not always under ideal conditions of sterility. Nevertheless, the conditions provided by the natural environment extensively influence the characteristics of the final product. In this way, research on fermentable food seeks to standardize traditional fermented food and beverages to improve their organoleptic properties and optimize the time of the fermentation. Table 2 shows different raw materials used as substrates in traditional food beverages.

The most commonly used substrates are fruits, vegetables, meat, and cereals. Between the traditional alcoholic fermentations based on fruits are the well-known wine and cider. They are firstly fermented by S. cerevisiae, with a secondary malolactic fermentation induced by LAB, which improves the flavor and aroma of the final product (Alexandre et al. 2004). Lactobacillus, Oenococcus, Pediococcus, and Leuconostoc have been reported as the predominant genera during malolactic fermentation in winemaking (García, Rendueles, and Díaz 2019).

Vegetables are another important substrate. Vegetables are rich in carbohydrates, proteins, minerals, amino acids, and phytochemicals. Around the world, vegetables are a substrate of different fermented beverages. The chemical composition of the substrate depends on the geographical location and climatic conditions where the crop is obtained. Also, the harvesting time and consequently the degree of 
Table 2. Classification of raw materials in fermented food substrates.

\begin{tabular}{|c|c|c|c|}
\hline Raw material & & Fermented beverage & Reference \\
\hline \multirow[t]{24}{*}{ Cereals } & Rice & Ang-Kak & Steinkraus (1996); Tamang and Kailasapathy (2010) \\
\hline & & Boza & Blandino et al. (2003); Tamang and Kailasapathy (2010) \\
\hline & & Dosa & Soni et al. (1986); Tamang and Kailasapathy (2010) \\
\hline & & idli & Tamang and Kailasapathy (2010) \\
\hline & & Khamak & Alexandraki et al. (2013) \\
\hline & & Lao-chao & Blandino et al. (2003); Tamang and Kailasapathy (2010) \\
\hline & & Puto & Steinkraus (2004); Tamang and Kailasapathy (2010) \\
\hline & & Selroti & Yonzan and Tamang $(2010,2013)$ \\
\hline & & Tape & Steinkraus (1996); Tamang and Kailasapathy (2010) \\
\hline & & Ketan & \\
\hline & Maize & Busa & Hancioğlu and Karapinar (1997); Altay et al. (2013) \\
\hline & & Boza & \\
\hline & & Bosa & \\
\hline & & Gowé & Greppi et al. (2013) \\
\hline & & Kenkey & Oguntoyinbo et al. (2011) \\
\hline & & Kunu-zaki & Olasupo et al. (2010); Oguntoyinbo et al. (2011) \\
\hline & & Koko & Blandino et al. (2003); Tamang and Kailasapathy (2010) \\
\hline & & Mawè & Greppi et al. (2013) \\
\hline & & Ogi & Greppi et al. (2013) \\
\hline & & Poto poto & Abriouel et al. (2006); Tamang and Kailasapathy (2010) \\
\hline & & Pozol & $\begin{array}{l}\text { Díaz-Ruiz et al. (2003); Castillo-Morales, Wacher-Rodarte, } \\
\text { and Hernández-Sánchez (2005) }\end{array}$ \\
\hline & Sorghum & Hussuwa & Yousif et al. (2010) \\
\hline & & Kunu-zaki & Oguntoyinbo et al. (2011) \\
\hline & & Togwa & Mugula et al. (2003); Tamang and Kailasapathy (2010) \\
\hline \multirow[t]{9}{*}{ Vegetables } & Cucumbers & Cucumbers fermented & Tamang and Kailasapathy (2010) \\
\hline & & Jiang-gua & Chen et al. (2012) \\
\hline & & Khalpi & Tamang and Kailasapathy (2010) \\
\hline & Cabbage & Paocai & Yan et al. (2008) \\
\hline & & Sauerkraut & Johanningsmeier et al. (2007) \\
\hline & Turnip & Sunki & Watanabe et al. (2009) \\
\hline & Shalgam & & \\
\hline & Soybean & Bekang & Chettri and Tamang (2014) \\
\hline & & Douchi & Wang et al. (2006) \\
\hline \multirow[t]{2}{*}{ Fruits } & Grape & Wine & $\begin{array}{l}\text { Bahiru, Mehari, and Ashenafi (2006); Tamang and } \\
\text { Kailasapathy (2010) }\end{array}$ \\
\hline & Apple & Cider & Tamang and Kailasapathy (2010) \\
\hline \multirow[t]{2}{*}{ Plants } & Agave & Tequila & Escalante et al. (2004); Aldrete-Tapia et al. (2020) \\
\hline & & Pulque & Escalante et al. (2004, 2016); Torres-Maravilla et al. (2016) \\
\hline
\end{tabular}

maturity of the raw material used is not always exactly the same for every processing. The substrate of Shalgam is black carrot (Erten, Tanguler, and Canbaş 2008). Black carrot contain sugars such as a sucrose, glucose, and fructose (1.20-3.31, $1.10-5.60,1.00-34.36 \mathrm{~g} / 100 \mathrm{~g}$, respectively), that are fermented by LAB and yeasts (Kammerer, Carle, and Schieber 2004). An important component of black carrots are carotenoids, the most important being anthocyanins, and cyanidine glycosides (acylated with p-coumaric, ferulic, p-hydroxybenzoic and synapic acids), peonidine and pelargonidine glycosides (Kammerer, Carle, and Schieber 2003). In fact, the purple-red coloring of the Shalgam is related to the pigments of the anthocyanins of the black carrot and $\beta$-carotenes found in carrots. Mineral content in black carrot includes sodium, potassium, calcium, magnesium, and phosphorus. These compounds available are used for the microorganisms growth, transforming biochemically and organoleptically the substrates, and producing different metabolites that enrich the food with different micronutrients (vitamins, minerals, amino acids, etc.) (Ghosh et al. 2015).

Pulque is a fermented beverage that use as substrate a plant (Agave). Agave sap contains sugars (sucrose, fructose, and glucose), vitamins, minerals, and amino acids. It has been reported to protect against free radical damage that can lead to cancer, heart attack, and stroke, so it is a source of nutrition. Agave sap has a high diversity of microorganisms, which determine the attributes of Pulque. It is rich in different compounds favorable for microorganisms naturally associated with agaves. Microorganisms are transported to the scraped cavities of the stems through the air or the action of scrapers and other utensils used for collecting agave sap (Álvarez-Ríos, FigueredoUrbina, and Casas 2020).

Cereals are other substrate used in fermented beverages. Between the mostly common products obtained by fermentation of cereals is the traditional beer, which is mainly fermented by the action of $S$. cerevisiae. Nevertheless, other microorganisms may also be involved. For example, Belgian lambic beer is traditionally produced by spontaneous fermentation involving Enterobacteriaceae and LAB species (Spitaels et al. 2015; De Roos and De Vuyst 2018). In this case, the cereals have adequate nutrients that become a viable medium for the growth of LAB. This influences the organoleptic properties of the final product, since it eliminates the "green" and unpleasant taste associated with raw cereals in the beer (Peyer, Zannini, and Arendt 2016).

A wide diversity of cereals such as millet, oats, barley, rice, corn, and others have been used. Their rich chemical 
composition makes them feasible to be used as substrates in different fermented foods and beverages. Cereals have been used as raw materials for many years to develop products through fermentation in different countries. In general, the cereal contain water, vitamins, minerals, carbohydrates, dietary fiber (DF) and proteins (Blandino et al. 2003).

Cereals are important source of hemicelluloses, which include arabinoxylans, $\beta$-glucans, and arabinogalactans, also called DF (Saulnier et al. 2007). DF are non-digestible components consisting of non-starch polysaccharides, resistant starch, oligosaccharides (mainly fructans), and carbohydratefree polyphenolic ether lignin. These polymers are present in the cell walls along with lignin, lignans, phenolic acids and small amounts of protein (McDougall et al. 1996). The cell walls of the outer part of the nucleus are thick and hydrophobic and are composed of cellulose, xylans, and significant amounts of lignin (Bach Knudsen et al. 2017).

Vitamins in cereals are micronutrients that are essential for the metabolism of all living organisms. They are found as precursors of intracellular coenzymes that are necessary to regulate vital biochemical reactions in the cell. It has been identified as a major source of thiamin in cereals (Capozzi et al. 2012). Cereals are also important sources of folates (Katan et al. 2009). Folate is mainly concentrated in the bran fractions (Kariluoto et al. 2006).

Minerals are micronutrients defined as chemical elements required by organisms to perform vital functions. The principal minerals in cereals are iron, zinc, copper, manganese, calcium, magnesium, potassium, and phosphorus (Berdanier, Dwyer, and Herber 2013).

All these components are used by the microorganisms as substrateto initiate the fermentation process. Boza is a traditional fermented beverage made of millet, cooked maize, wheat, or rice (Akpinar-Bayizit, Yilmaz-Ersan, and Ozcan 2010).

Millet are a rich source of carbohydrate, DF, protein, phytochemicals (phenolic acids, flavonoids, catechins, phytic acid, phytosterols, tocopherols, and tocotrienols), fat, calcium, iron, and Vitamin E (Rousseau et al. 2019). It has been reported to contain a low glycemic index. Since the release of glucose from millet into the blood is slow, this reduces the absorption of glucose. It also has low phytic acid, which helps reduce type 2 diabetes, weight loss, and the risk of heart disease (Malli and Tripathi 2015).

Another Boza substrate is a wheat bran that is a by-product of conventional wheat milling. Wheat contains several essential nutrients, including the B vitamin group (Capozzi et al. 2012). It is high in DF and contains phenolic compounds and flavonoids. These compounds promote health by reducing the risk of diabetes, hypertension and colon cancer (Kong et al. 2020).

Rice is another substrate of Boza, Chhang, and Bhaati jaanr. Rice is a cereal cultivated in India. This cereal contain carbohydrates, proteins, vitamins, mineral, and phytochemicals. Studies suggest that rice contains rice proteins and peptide fractions with antioxidant, hypertensive, anticarcinogenic and anti-obesity effect (Amagliani et al. 2017).

Corn is a plant of American origin that is consumed worldwide (Velu et al. 2006). There are different varieties of the corn part of the conventional yellow corn. The major physical structures of maize are: endosperm $(82-83 \%)$, germ (10-11\%), pericarp (5-6\%), and tip cap $(0.8-1.0 \%)$. Gross maize grain composition is $68-74 \%$ starch, $8-11.5 \%$ protein, and $4-5.5 \%$ fat. The pericarp is source of crude fiber ( $87 \%)$, consisting mainly of hemicellulose (67\%) and cellulose (23\%), with only a small fraction of lignin (0.1\%) (LópezHernández et al. 2018). Corn contains phenolic acids and anthocyanins. Phenolic acids are the most effective natural antioxidants. In vitro and in vivo studies have shown that phenolic acids have various biological properties, such as free radical scavenging, ulcer control, allergy, anti-inflammatory, and anti-tumor activities (Chen et al. 2017). Corn is the substrate of different fermented beverages, such as Boza, Atole agrio, and Pozol. During the fermentation of the Pozol the polysaccharides are hydrolyzed by the LAB. These drinks are considered prebiotic because of their DF. Cereal fiber has been reported to stimulate the growth of beneficial colonic microbiota (De Munter et al. 2007). On the other hand, LAB are responsible for the characteristic flavor and aroma of the sour Atole agrio, that is directly related to the volatile organic compounds produced during fermentation (Väkeväinen et al. 2020). Volatile organic compounds are derived from amino acids, peptides, and fatty acids. Some of the volatile organic compounds responsible for generating aroma are acetaldehyde, acetone, butan-2-one, butane-2,3dione (diacetyl), and 3-hydroxybutan-2-one (acetoin) (Lee et al. 2019).

\section{Compounds from fermented beverages with bioactive potential}

The transformation of the natural components of the raw material takes place during the fermentation process. Microorganisms involved in the fermentation produce enzymes, such as proteinase, amylase, mannase, cellulase, and catalase, able to decouple complex compounds into simple bio molecules. By alteration of the nutritional and bioactive properties of the food matrices, new compounds with biological activities are synthesized, which may affect beneficially the human health (Tamang and Nikkuni 1996; Chettri and Tamang 2014; Cifelli et al. 2017).

The nutritional quality of foods obtained by fermentation involve three factors: the microorganisms, the substrate and the environmental conditions. Changes occurring during the fermentation due to the action of LAB may be classified into five stages (Figure 1). In a first stage, sugars are transformed into end products, such as simpler acids, carbon dioxide and alcohols. This in turn leads to an increase of the nutrients available in the food. In a second stage, polymers are hydrolyzed and bioactive compounds are enzymatically synthesized, such as antioxidants. In a third stage the bioavailability of nutritive compounds and the concentration of vitamins and amino acids is enhanced, and there is a greater bioavailability of phytochemicals and minerals. Later, in stage 4 , the toxic and anti-nutritional compounds are degraded. Finally, the synthesis of promoters for absorption and uptake occurs (van Hylckama Vlieg et al. 2011). 


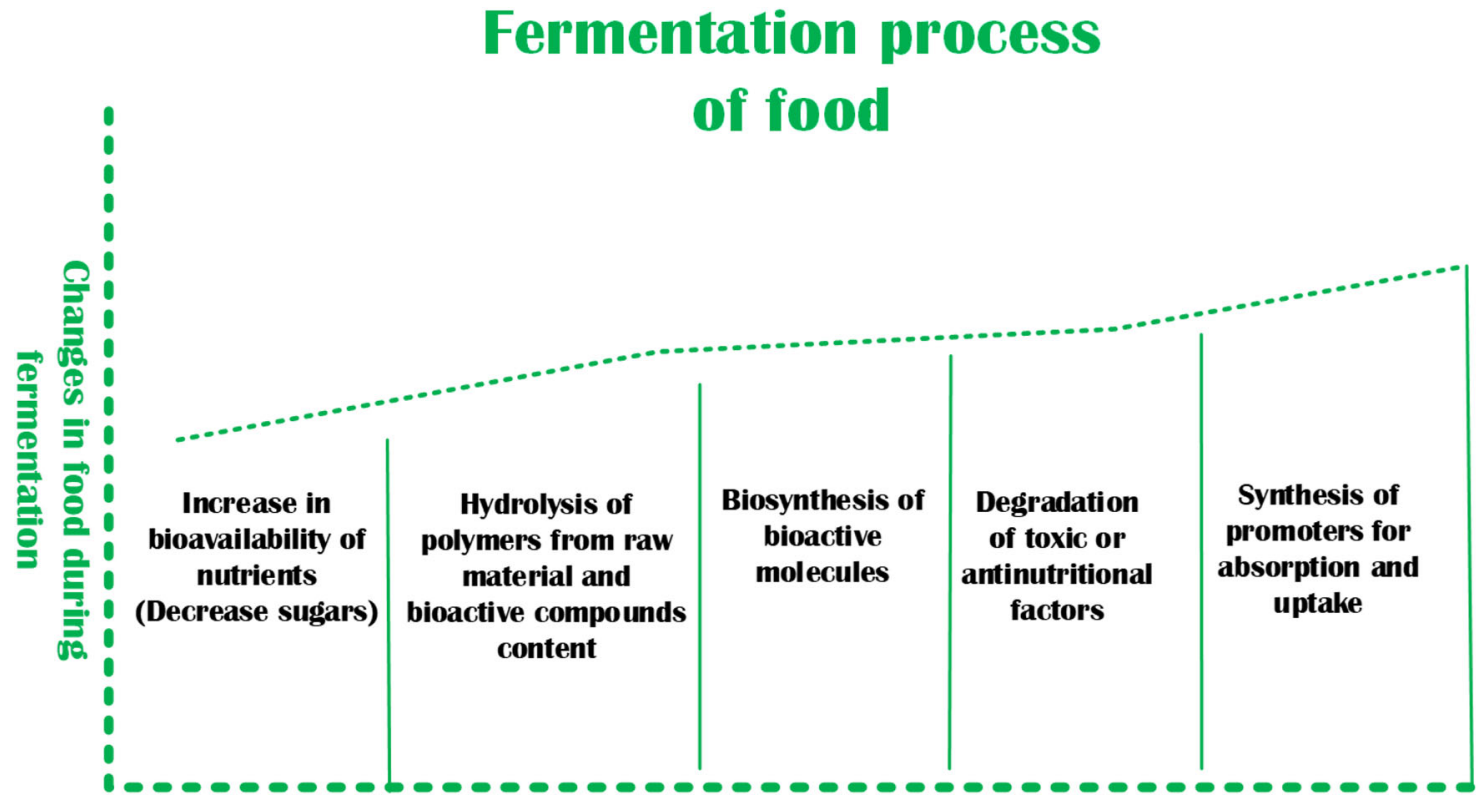

Figure 1. Fermentation process of food.

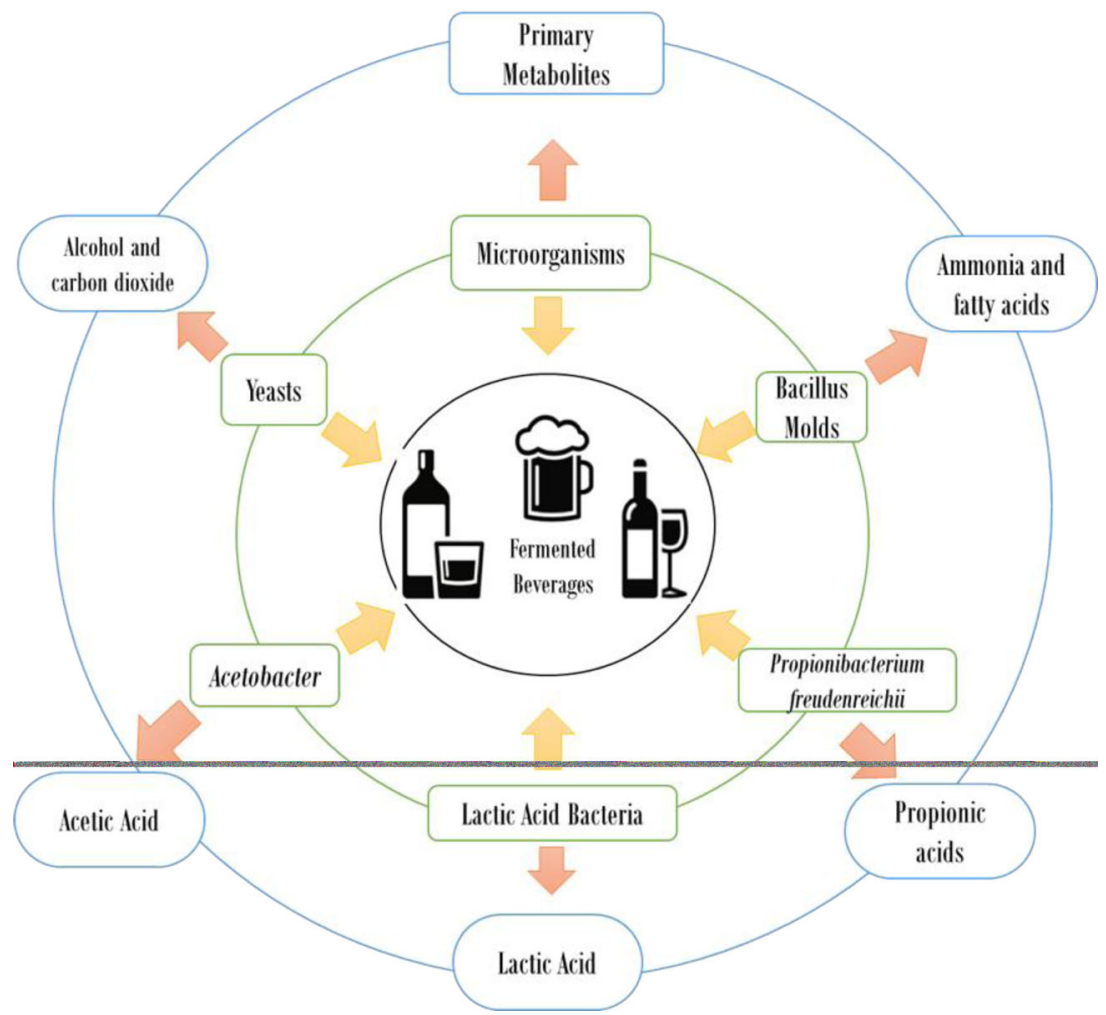

Figure 2. Beverage fermentation process and including the relationship between microorganisms and the primary metabolites found.

Studies have shown that the secondary metabolites may bring specific benefits to the human health. The biogenic effect is related with the specific metabolic pathway of the microorganisms, so that different biochemical mechanisms allow them to fulfill their role as efficient cellular factories for the synthesis and release of health promoting compounds (Figure 2).

Another factor resulting from the fermentation process is the increased bioavailability of nutritional compounds. Meaning that by fermentation, the rate and extent to which the compound is absorbed and made available to the host cell metabolism is trigged. During the process of gastrointestinal digestion, compounds are released from food, followed by absorption by epithelial cells, tissue distribution and bioactivity. For example, bioactive peptides released by the probiotic bacteria have an antimicrobial effect, by acting against pathogenic bacteria, that in turn improve the immune system (Septembre-Malaterre, Remize, and Poucheret 2018).

The nutritional properties are also modified with fermentation, as there is a reduction in the level of carbohydrates 
such as polysaccharides and non-digestible oligosaccharides. The presence of amino acids and their availability is altered with the fermentation conditions, such as low $\mathrm{pH}$, which is optimal to begins enzymatic activity. For example, in the fermentation of cereals when the $\mathrm{pH}$ decreases, the present phytate begins to degrade; when the phytate is reduced, the bioavailability of iron and other minerals increases (Blandino et al. 2003).

Yeasts are part of bacterial consortiums in fermented foods. Which play a key role in the production of bioactive metabolites such as single-cell proteins, nanoparticles ethanol, aldehydes, isobutanol, isoamyl alcohol, esters, free oils, aromatics compounds, such as a 4-ethylguiacol and 4-ethylphenol folate, carotenoids, Y-amino, butyric acid, antimicrobial peptides, melatonin, 4-hydroxy-2(or5)-ethyl-5(or 2)methyl-3(2H)-furanone (HEMF) and phenolic compounds. They also produce hydrolytic enzymes responsible for the transformation of bioactive molecules such as amylase, lactase, xylanase, cellulase, phytase, lipase, inulinase, and superoxide dismutase, $\beta$-glucosidase, $\beta$-galactosidase, and fructosyl transferase (Chaves-López et al. 2012; Mu, Yang, and Yuan 2012; Akabanda et al. 2013; Chi et al. 2016). When yeasts degrade the substrate of fermented beverages there is a production of oligosaccharides, polyphenols lactulose oligosaccharides and xylo-oligosaccharides and carotenoids, showing the potential of yeasts for the development of biotechnological foods by creating new products with nutraceutical value (Bhataya, Schmidt-Dannert, and Lee 2009; Rai et al. 2016; Han et al. 2017; Rodriguez et al. 2017).

Research has shown that traditional fermented beverages, such as Boza fermented drink, are a source of bioactive compounds, which makes the drink a beverage with functional properties (Botes et al. 2007). Boza is a source of probiotics, prebiotics (from exopolysaccharides (EPS) produced by LAB), bioactive peptides (with anti-hypertension activity), and DF (from the cereals used as substrate). Probiotics and prebiotics have been extensively reported to prevent and treat gastrointestinal health diseases, colon cancer, allergies, obesity, insulin resistance syndrome, type 2 diabetes, hypertension, osteoporosis, among others (Nobre et al. 2015; Markowiak and Śliżewska 2017; Salmerón 2017).

LAB have the ability to produce extracellular polymers known as microbial (EPS) (Vu et al. 2009). EPS are produced during the growth of bacteria and have a generally recognized safe status (GRAS); these substances contain certain antibiotic peptides and bioactive compounds with nutraceutical properties and functions (Abedfar et al. 2020). EPS can be used to improve the rheological properties, texture and stabilization of foods. They have been used as good viscosity agents, stabilizers, emulsifiers, as well as gelling agents in foods and pharmaceutical products (Sanalibaba and Cakmak 2016).

Peptides are derived from proteins. These proteins are often cryptic and dormant until proteolytic release of the active peptides. The release can occur by enzymatic activity during gastrointestinal digestion or during ripening and fermentation (Amorim et al. 2019). Among the various types of bioactive peptides, angiotensin converting enzyme (ACE) inhibiting peptides have been the most studied for their potential in the prevention and treatment of hypertension. ACE is a key enzyme for the regulation of blood pressure through the renin-angiotensin system $(\mathrm{Wu}$, Liao, and Udenigwe 2017). Whole grain consumption has been associated with a reduced risk of developing several chronic diseases, such as coronary heart disease, arteriosclerosis, type 2 diabetes and some types of cancer (Cho et al. 2013). Cereals are a source of DF and a wide variety of phytochemicals. Physiologically, non-starch soluble polysaccharides contribute to increased viscosity in the small intestine, as this can influence the rate and extent of digestion and absorption. Cereals contain phenolic and lignan phytochemicals. Phenolics are absorbed in the small intestine, and another macronutrient passes to the large intestine, where the microbiota, which degrades and metabolizes DF into SCFAs and gases, also converts phenolic compounds into a few other metabolites. These metabolites are absorbed by the body and have the ability to influence metabolism at the cellular level (Bach Knudsen et al. 2017).

Arslan-Tontul and Erbas (2019) enriched the protein content of probiotic Boza by the addition of gluten, zein, and chickpea flour. Its probiotic potential was evaluated by co-culture fermentation of the cereal medium with $L$. acidophilus, Bifidobacterium bifidum, and Saccharomyces boulardii. Chickpea added to Boza provided the highest cell counts of $L$. acidophilus (7.92 log CFU/g), B. bifidum (7.32 log $\mathrm{CFU} / \mathrm{g}$ ), and $S$. boulardii (3.26 log CFU/g during storage. With the addition of gluten, the protein content of the sample was enriched four times as compared with control Boza. During fermentation and storage, a total of 36 different compounds were identified with the major compounds as 9 , 12-octadecadienoic acid, 9-octadecenoic acid, hexadecanoic acid and hexadecanoic acid, 2-hydroxyl-1-(hydroxymethyl) ethyl ester. The concentration of volatile compounds generally decreased during storage of samples.

Shalgam is made from black carrots and its bioactive compounds are provided by the raw material, which is rich in anthocyanins, phenolic compounds, vitamins and minerals. The anthocyanins are flavonoids with recognized antioxidant properties (Tanriseven et al. 2020). These antioxidants have anti-cancer, anti-tumor, and anti-inflammatory properties which may prevent cardiovascular diseases (Kong et al. 2003). Anthocyanins as cyanidin-3-glycoside were quantified in Shalgam in a concentration up to $114.1 \mathrm{mg} / \mathrm{L}$ (Erten, Tanguler, and Canbaş 2008). Other phenolic compounds present in black carrot are chlorogenic acids, which are derivatives of hydroxycinnamic acid generated by the esterification of cinnamic acids (caffeic, ferulic, p-coumaric, and (-)-quinic acids) (Mizgier et al. 2015). On the other hand, LAB also help to increase the immunity against pathogenic bacteria, as well as regulating the intestinal microbiota. It has been reported that in Shalgam, the most important compound formed is the lactic acid or lactate, which results from lactic fermentation. Lactic acid is produced in an average concentration of $6.81 \mathrm{~g} / \mathrm{L}$. It provides changes in the taste and aroma of the drink (Erten, Tanguler, and Canbaş 2008). 
In the case of Leben, it is the substrate (milk) that gives the chemical, microbiological and sensory properties to the fermented food. Through the interaction of milk with LAB, bioactive compounds (sterols, fibers, vitamins, minerals, organic acids) are obtained. In addition to the production of bacteriocins (Bach Knudsen et al. 2017). In Leben, organic acids are produced during fermentation, which potentially inhibits the proliferation of Escherichia coli and other coliforms. A proteolytic activity has also been reported in Leben associated to the yeasts (Samet-Bali et al. 2017).

Chhang is a rice-based drink. Rice contains vitamins, proteins, polyphenolic compounds (phytic acid, ferulic acid, and oryzanols). During fermentation of rice produced, biologically active metabolites such as amino acids, organic acids, phenolic acid, ferulic acid, vanillic acid, protocatechuic acid, phytic acid, inositol, and antimicrobial metabolites. Many plant phenols are often biologically unavailable after intake, such as ferulic acid, thus, fermentation can improve antioxidant potential of food (Sindhu and Khetarpaul 2002). Antimicrobial metabolites have been identified in Chhang, including organic acids, diacetyl, hydrogen peroxide, antibiotics, and bacteriocytes related to the indigenous microorganisms (usually LAB). In vitro studies shown that $L$. plantarum F22 isolated from Chhang holds probiotic features, since it showed resistance to the extreme conditions of the gastric simulation (Handa and Sharma 2016).

In the case of Chal, which is a milk-based fermented beverage, the functional properties are derived from the interaction of the substrate with the LAB. Tamang and Thapa (2006) investigated the isolation and identification of LAB from Chal and studied the antioxidant activity of camel and bovine milk fermented with LAB. Post-fermentation results showed that fermented camel milk has higher antioxidant activity than bovine milk. The fermented milk of camel with L. lactis SM10 showed better organoleptic properties and higher values of antioxidant activities-DPPH $(57.90 \mu \mathrm{m})$ and ABTS $(148.35 \mu \mathrm{m})$-as compared to other strains (Soleymanzadeh, Mirdamadi, and Kianirad 2016).

It has been reported, that from the $88 \mathrm{LAB}$ strains isolated from Atole agrio, $87.5 \%$ were identified as folates producers, $71.6 \%$ degraded phytates, $38.6 \%$ produced exopolysaccharides, $12.5 \%$ showed amylolytic activity, and $81.8 \%$ were resistant to antibiotics. Atole agrio has been used by indigenous and mestizo groups from South-East Mexico not only for its nutritional value, but also for medicinal and ceremonial purposes (Väkeväinen et al. 2018). It has been reported that low $\mathrm{pH}$ in sour Atole agrio is related to antimicrobial activity against gram-negative microorganisms.

Microbiological and biochemical changes produced during the fermentation of the Chorote have been reported. At the end of the process there is a decrease in $\mathrm{pH}$ (up to 4.2), which is related to the production of lactic acid, an increase in total protein $(103.0-152.7 \mathrm{~g} / \mathrm{kg})$ and soluble protein $(6.1-31.9 \mathrm{~g} / \mathrm{kg})$, and an increase in available amino acids, such as lysine and tryptophan. Fungi, yeasts, lactic amylolytic acid, and nitrogen-fixing bacteria have been observed to increase during fermentation (Castillo-Morales, WacherRodarte, and Hernández-Sánchez 2005).
Pozol has a great microbiological diversity, thus, the production of bioactive compounds from microorganisms isolated from Pozol has been studied. Phister, O'Sullivan, and McKay (2004), identified three antimicrobial compounds produced by a Bacillus sp. strain CS93 isolated from Pozol, named bacilysin, chlorotetaine, and iturin. These compounds were associated to the medicinal properties attributed to Pozol. Later, it was found that the same bacteria is able to produces also bioactive lipopeptides, which are versatile molecules, in which peptides are attached to lipid chains. These lipopetides may also have medicinal properties and have been used as antibiotics (Moran et al. 2010).

Several bioactive compounds produced from Pulque fermentation have been reported, highlighting the presence of vitamin C (Racaño 2000), but also other vitamins such as pantothenic acid, thiamin, p-amino benzoic acid, pyridoxine, biotin ascorbic acid and riboflavin (Sanchez-Marroquin and Hope 1953). It has also been reported that Pulque is a source of amino acids such as Ile, Leu, Lys, Cys, Phe, Tyr, Thr, Trp, Val. It has also been reported that Pulque provides a significant amount of iron (Morales de León, Bourges, and Camacho 2005).

Giles-Gómez et al. (2016) evaluated in vitro and in vivo the probiotic potential of the L. mesenteroides $\mathrm{P} 45$ strain isolated from Pulque. The strain showed resistance to lysozyme, low $\mathrm{pH}$ conditions (3.5) and bile salts $(0.1$ and $0.3 \%$ oxgall). It also showed antibacterial activity against pathogenic strains, such as Listeria monocytogenes, E. coli, Salmonella entérica serovar Typhi and Salmonella entérica serovar Typhimurium. In vivo tests run with a mice model showed an anti-infectious activity of $L$. mesenteroides $\mathrm{P} 45$ against $S$. entérica serovar Typhimurium. Torres-Maravilla et al. (2016) isolated L. sanfranciscensis LBH1068 from Pulque and evaluated its potential as a novel anti-inflammatory probiotic strain.

Although traditional spontaneous fermented beverages, which are consumed worldwide, have shown an interesting potentialas a source of bioactive compounds, they are not standardized beverages and are their bioactive compounds content may significantly vary for the same product produced in different batches. Thus, they are not produced by the food industry and are not for sale in the functional food market. It is true that studies arguing their functionality as such are lacking, but traditional fermented beverages are still a source of bioactive compounds.

\section{Bioactive compounds: beneficial health effects}

As mentioned in the previous section, fermented beverages are a source of bioactive compounds because through biosynthesis and biotransformation new derived compounds with bioactive potential are generated. These bioactive compounds fulfill specific functions in the human body. These are exerted by the active principles of the substances. They influence the cellular activity and the mechanisms in the body, which help to promote health (Figure 3).

Bioactive compounds produced from these fermentations have several positive applications in human health. These bioactive compounds have been studied in vitro and in vivo to demonstrate their relationship with the improvement of 


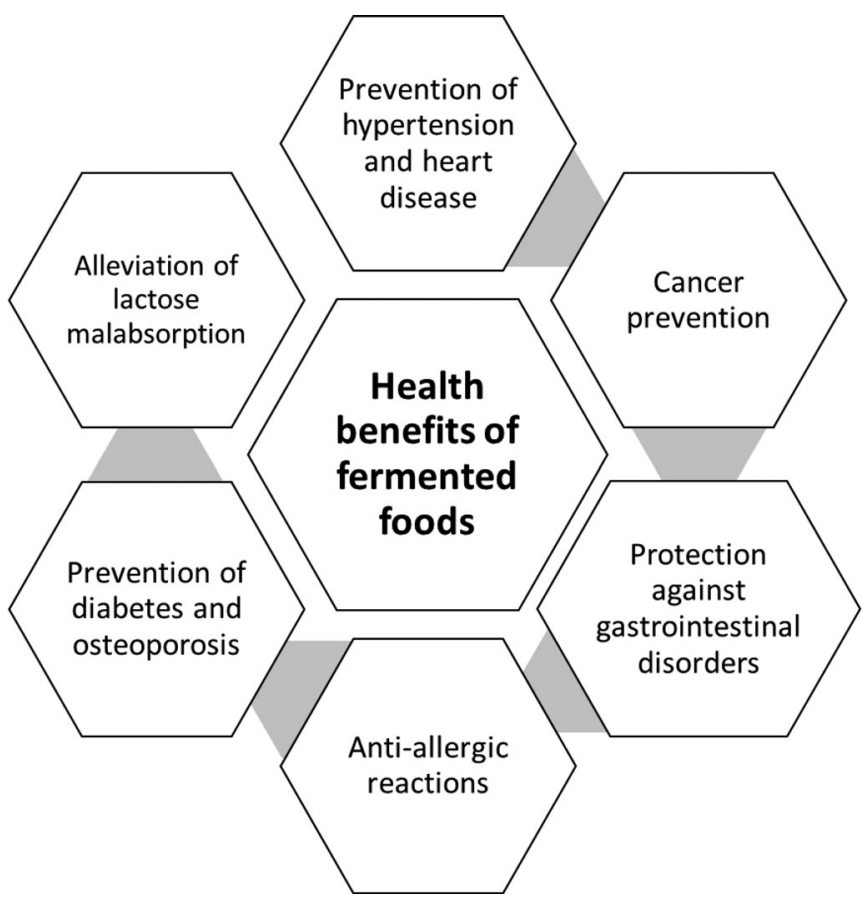

Figure 3. Heal benefits of fermented foods.

chronic degenerative diseases. Some of the activities provided by microorganisms isolated from fermented beverages are summarized in Table 3.

One of the most important degenerative diseases, affecting about a quarter of the world's population, is hypertension, which is a major but controllable risk factor in cardiovascular disease and related complications. Compounds that play a role in the regulation of blood pressure by reducing ACE activity are known as ACE inhibitors. Inhibition of ACE, which is one of the health effects of bioactive peptides, is considered a useful therapeutic approach in the treatment of hypertension (Korhonen and Pihlanto 2006; Akıllığlu and Karakaya 2009).

There are many studies concerning ACE-inhibitory peptides and ACE-inhibitory activities of meat, fish, milk, fermented dairy products and eggs (He, Liu, and Ma 2013). Kancabaş and Karakaya (2013), studied ACE inhibitory activity of protein hydrolysate and protein fractions obtained from $B o z a$, and determined the effect of in vitro digestion on the ACE inhibitory activity of Boza. The protein content of the hydrolysate obtained after digestion was found to be lower than that of the Boza, but the inhibitory activity of the hydrolysate ACE was significantly higher $(p<0.05)$. The protein hydrolysate was separated into three fractions according to molecular weight, and the separate protein fractions inhibited ACE activity. The IC50 values of the fractions revealed that the ACE-inhibitory activity of Boza increased 3.5-fold after stomach digestion. Results showed that Boza can be considered a good source of ACE-inhibiting peptides.

Other studies on the beneficial effects provided by bioactive compounds have been exploring its antimicrobial activity. Antimicrobial activity is related with the probiotic microorganisms. The mechanism of action that results in the antimicrobial activity is described by the competitive growth effect that inhibits the multiplication of pathogenic bacteria. During fermentation, probiotics create a favorable environment (lowering the $\mathrm{pH}$ and reducing the availability of oxygen), that allows the release of bacteriocins which counteract the growth of pathogenic microorganisms (Koebnick et al. 2003; Bekkali et al. 2007; Turan et al. 2015). In addition, some studies suggest that probiotics can play a beneficial role in relieving the symptoms of constipation, at least with certain strains of probiotics. Due to the fermentation of fiber in the intestine, the synthesis of essential micronutrients such as vitamins, amino acids and enzymes takes place, improving the metabolic activity of carbohydrates (Chugh and Kamal-Eldin 2020).

Cervantes Elizarrás et al. (2019) studied isolated and identified LAB from Aguamiel and Pulque and evaluate their probiotic potential and effect against Helicobacter pylori. They reported that $60 \%$ of the isolates exhibited antimicrobial activity against E. coli and Staphylococcus aureus. The growth of H. pylori ATCC 43504 was suppressed by all the $\mathrm{LAB}$, and the urease activity from all the H. pylori strains was inhibited, which may decrease its chances for survival in the stomach. The results suggest that LAB isolated from Pulque and Aguamiel could be an option to establish a harmless relationship between the host and $H$. pylori, helping in their eradication therapy.

The probiotic potential of 14 strains isolated from Pulque was recently tested. The isolates belonged from the following phylogenetic groups: L. plantarum, L. paracasei, L. brevis, and Lactobacillus composti. Bacteria resistance for lysozyme, low $\mathrm{pH}$, and bile acid was evaluated. Strains adherence to human intestinal epithelial cells and respective immunomodulatory properties were also evaluated. Bacterial strains with antiinflammatory properties were then tested in vivo using an induced chronic colitis mouse model. A reduction of weight loss, significant decreased in gut permeability, and cytokine modulation was found for mice treated with the lactobacilli isolated from Pulque. In particular, the L. sanfranciscensis LBH1068, shown high potential as a probiotic to treat inflammatory bowel diseases (Torres-Maravilla et al. 2016).

Based on the Brazilian indigenous beverage Cauim, a blend of cassava and rice was fermented with indigenous strains L. plantarum from Cauim and T. delbrueckii from Tarubá, and the commercial probiotic L. acidophilus. Fermentation with the co-culture of the LAB strains shown to confers potential health benefits to the fermented product. It has been reported that L. plantarum can decrease intestinal heavy metal absorption, reduce metal accumulation in tissues, and alleviate hepatic oxidative stress (Behera, Ray, and Zdolec 2018). In addition, L. plantarum has antioxidant properties. These bacteria colonize the intestinal tract and play a key role in protecting against free radicals. L. plantarum also contributes to the preservation of various disorders such as diabetes, cardiovascular disease, and ulcers of the gastrointestinal tract (Kaushik et al. 2009). Safety of the food was improved by the resultant acidification and production of organic acids. The yeast strain $T$. delbrueckii showed to improve the product's digestibility by reducing 
Table 3. Bioactive compounds and functional properties of fermented foods.

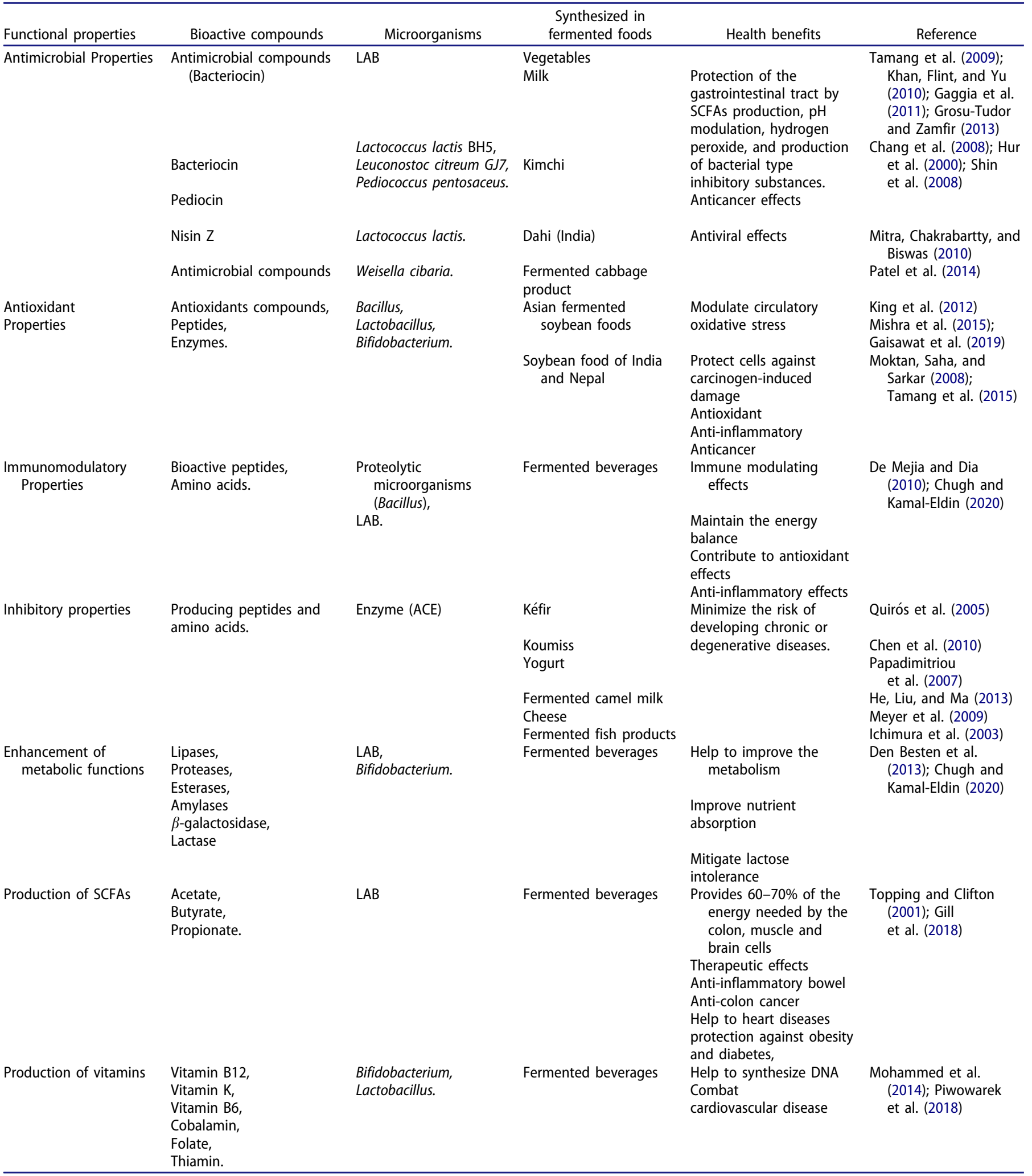

starch, increasing the antioxidant activity, and further stimulating LAB growth during fermentation (Freire et al. 2017).

Polyphenols derivate from secondary metabolites originates from primary metabolites (carbohydrates, amino acids, and lipids). They are known as strong natural antioxidants, having key role in wide range of biological and pharmacological properties, such as anti-inflammatory, anticancer, antimicrobial, antiallergic, antiviral, antithrombotic, hepatoprotective, food additive, signaling molecules, and many more. Hence the importance of being studied and 
incorporated into food beverages (Kumar and Goel 2019; Kumar et al. 2019). Changes in polyphenols during Shalgam fermentation was recently studied. It was observed that total phenolic content, anthocyanins content and total antioxidant capacity greatly increase in the first 12 days of fermentation. The recovery of the Shalgam drink was largely identical to the black carrot results in terms of flavonoids, phenols and anthocyanins (identified as cyanidin), and antioxidant capacity, after in vitro digestion. The amount of beneficial compounds in the early fermentation stage was found significantly less than with the final product. The degradation of phenolics and anthocyanins was observed after the bioaccessibility tests (Toktaş, Bildik, and Özçelik 2018).

The SCFAs that are produced during fermentation with $\mathrm{LAB}$, specifically the butyrate, have been associated to integrity maintenance of the intestinal mucosa (Kort et al. 2015). Butyrate may reduce the risk of developing colon cancer, by reducing cell proliferation and stimulating cell differentiation. It is also associated with maturation of the enteric neurons. In addition, SCFAs have been identified as important modulators of the immune system, helping chronic inflammation (Lee et al. 2015).

Through the review conducted, it was observed that there are many studies discussing bioactive compounds (phenolic compounds, antioxidants, bioactive peptides, etc.) and their beneficial effects on human health. However, few studies approach the relationship between traditional fermented foods, bioavailability and bioaccessibility of these bioactive compounds.

The scientific challenge is to perform in vitro and in vivo studies, in addition to study the interactions of the compounds, the digestion, absorption and metabolism pathways. Also to understand the bioaccessibility and bioavailability of the functional properties of the traditional fermented foods, as a source of bioactive compounds, and its impact on the human health. This knowledge will certainly expand the market for traditional fermented beverages consumed worldwide.

\section{Future trends and conclusions}

Currently, science and technology face a major challenge in the creation, development and improvement of foods with additional health properties, the so-called functional foods, to meet consumer's expectations. Food have been fermented for years, and this is still a good process for extending shelf life, improving sensory properties and even their nutritional properties, as secondary metabolites with high biological value are produced during fermentation, that can help minimize some chronic degenerative diseases. In this context, it is important to study the traditional spontaneous fermented beverages in depth, and to identify the mechanisms underlying the relationship established between the LAB and the rest of the microbiota. As well as to better understand the participation of the metabolites generated.

Since these drinks are consumed in several countries, and they are well reported as a source of new bioactive compounds, by improving its conditions of production they can be used in the development of new products with added functional properties, as well as in the optimization and design of new food bioprocesses.

As a final remark, although it has been reported that fermented foods are a good source of bioactive compounds, very few studies have been conducted to disclose the relationship between the intake of traditional fermented foods and their impact on human health.

\section{Disclosure statement}

The authors declare no conflict of interest.

$\begin{array}{ll}\text { Abbreviations } \\ \text { AAC } & \text { Acetic acid bacteria } \\ \text { ABTS } & 2,2^{\prime} \text {-azinobis-(3-ethylbenzothiazoline-6-sulfonic acid) } \\ \text { ACE } & \text { Angiotensin converting enzyme } \\ \text { CFU } & \text { Colony forming units } \\ \text { DPPH } & \text { 2,2-diphenyl-1-picrylhydrazyl } \\ \text { DF } & \text { Dietary fiber } \\ \text { EPS } & \text { Exopolysaccharide } \\ \text { LAB } & \text { Lactic acid bacteria } \\ \text { SCFAs } & \text { Short chain fatty acids } \\ \text { w/v } & \text { weight/volume }\end{array}$

\section{Funding}

The authors acknowledge the National Council of Science and Technology (CONACYT, Mexico) for the financial support (CVU 559365). This study was also supported by the Portuguese Foundation for Science and Technology under the scope of the strategic funding of UID/BIO/04469/2019 unit and BioTecNorte operation (NORTE-010145-FEDER-000004) funded by the European Regional Development Fund under the scope of Norte2020 - Programa Operacional Regional do Norte also, Project ColOsH 02/SAICT/2017 (POCI-01-0145FEDER-030071).

\section{ORCID}

Clarisse Nobre (D) http://orcid.org/0000-0001-9693-2395

Rosa M. Rodriguez-Jasso (D) http://orcid.org/0000-0001-8971-0639

Héctor A. Ruíz (D) http://orcid.org/0000-0003-0917-0324

Araceli Loredo-Treviño (D) http://orcid.org/0000-0002-2857-3340

Ruth Belmares (DD http://orcid.org/0000-0003-1362-4691

\section{References}

Abedfar, A., S. Abbaszadeh, M. Hosseininezhad, and M. Taghdir. 2020. Physicochemical and biological characterization of the EPS produced by $L$. acidophilus isolated from rice bran sourdough. LWT 127: 109373. doi: 10.1016/j.lwt.2020.109373.

Abriouel, H., N. B. Omar, R. L. López, M. Martínez-Cañamero, S. Keleke, and A. Gálvez. 2006. Culture-independent analysis of the microbial composition of the African traditional fermented foods poto poto and dégué by using three different DNA extraction methods. International Journal of Food Microbiology 111 (3):228-33. doi: 10.1016/j.ijfoodmicro.2006.06.006.

Akabanda, F., J. Owusu-Kwarteng, K. Tano-Debrah, R. L. K. Glover, D. S. Nielsen, and L. Jespersen. 2013. Taxonomic and molecular characterization of lactic acid bacteria and yeasts in nunu, a Ghanaian fermented milk product. Food Microbiology 34 (2):277-83. doi: 10.1016/j.fm.2012.09.025.

Akıllığlu, H. G., and S. Karakaya. 2009. Effects of heat treatment and in vitro digestion on the angiotensin converting enzyme inhibitory 
activity of some legume species. European Food Research and Technology 229 (6):915-21. doi: 10.1007/s00217-009-1133-x.

Akpinar-Bayizit, A., L. Yilmaz-Ersan, and T. Ozcan. 2010. Determination of Boza's organic acid composition as it is affected by raw material and fermentation. International Journal of Food Properties 13 (3):648-56. doi: 10.1080/10942911003604194.

Aldrete-Tapia, J. A., P. Escalante-Minakata, R. A. Martínez-Peniche, M. L. Tamplin, and M. Hernández-Iturriaga. 2020. Yeast and bacterial diversity, dynamics and fermentative kinetics during small-scale tequila spontaneous fermentation. Food Microbiology 86:103339. doi: 10.1016/j.fm.2019.103339.

Alexandraki, V., E. Tsakalidou, K. Ppadimitriou, and W. Holzapfel. 2013. Food and Agriculture Organization of the United Nations. www.fao.org

Alexandre, H., P. J. Costello, F. Remize, J. Guzzo, and M. GuillouxBenatier. 2004. Saccharomyces cerevisiae-Oenococcus oeni interactions in wine: Current knowledge and perspectives. International Journal of Food Microbiology 93 (2):141-54. doi: 10.1016/j.ijfoodmicro.2003.10.013.

Almeida, E. G., C. C. T. C. Rachid, and R. F. Schwan. 2007. Microbial population present in fermented beverage "cauim" produced by Brazilian Amerindians. International Journal of Food Microbiology 120 (1-2):146-51. doi: 10.1016/j.ijfoodmicro.2007.06.020.

Altay, F., F. Karbancioglu-Güler, C. Daskaya-Dikmen, and D. Heperkan. 2013. A review on traditional Turkish fermented nonalcoholic beverages: Microbiota, fermentation process and quality characteristics. International Journal of Food Microbiology 167 (1): 44-56. doi: 10.1016/j.ijfoodmicro.2013.06.016.

Amagliani, L., J. O’Regan, A. L. Kelly, and J. A. O'Mahony. 2017. The composition, extraction, functionality and applications of rice proteins: A review. Trends in Food Science \& Technology 64:1-12. doi: 10.1016/j.tifs.2017.01.008.

Amorim, F. G., L. B. Coitinho, A. T. Dias, A. G. F. Friques, B. L. Monteiro, L. C. D. d Rezende, T. d M. C. Pereira, B. P. Campagnaro, E. De Pauw, E. C. Vasquez, et al. 2019. Identification of new bioactive peptides from Kefir milk through proteopeptidomics: Bioprospection of antihypertensive molecules. Food Chemistry 282:109-19. doi: 10.1016/j.foodchem.2019.01.010.

Ampe, F., and E. Miambi. 2000. Cluster analysis, richness and biodiversity indexes derived from denaturing gradient gel electrophoresis fingerprints of bacterial communities demonstrate that traditional maize fermentations are driven by the transformation process. International Journal of Food Microbiology 60 (1):91-7. doi: 10.1016/ S0168-1605(00)00358-5.

Angmo, K., and T. C. Bhalla. 2014. Preparation of Phabs-an indigenous starter culture for production of traditional alcoholic beverage, Chhang, in Ladakh. Indian Journal of Traditional Knowledge 13: 347-351. Retrieved from http://nopr.niscair.res.in/bitstream/ 123456789/27929/1/IJTK 13\%282\%29 347-351.pdf

Arici, M., and O. Daglioglu. 2002. Boza: A lactic acid fermented cereal beverage as a traditional Turkish food. Food Reviews International 18 (1):39-48. doi: 10.1081/FRI-120003416.

Arslan-Tontul, S., and M. Erbas. 2019. Co-Culture probiotic fermentation of protein-enriched cereal medium (Boza). Journal of the American College of Nutrition. https://doi.org/10.1080/07315724. 2019.1612796

Axelsson, L. 1998. Lactic acid bacteria: Classification and physiology. In Lactic acid bacteria, Microbiology and functional aspects, eds. S. Salminen and A. Wright, 2nd ed., 1-72. New York: Marcel Dekker Inc.

Álvarez-Ríos, G. D., C. J. Figueredo-Urbina, and A. Casas. 2020. Physical, chemical, and microbiological characteristics of pulque: Management of a fermented beverage in Michoacán. Foods 9 (3): 361. doi: 10.3390/foods9030361.

Bach Knudsen, K. E., N. P. Nørskov, A. K. Bolvig, M. S. Hedemann, and H. N. Laerke. 2017. Dietary fibers and associated phytochemicals in cereals. Molecular Nutrition \& Food Research 61 (7):1600518. doi: 10.1002/mnfr.201600518.

Bahiru, B., T. Mehari, and M. Ashenafi. 2006. Yeast and lactic acid flora of tej, an indigenous Ethiopian honey wine: Variations within and between production units. Food Microbiology 23 (3):277-82 doi: 10.1016/j.fm.2005.05.007.

Baschali, A., E. Tsakalidou, A. Kyriacou, N. Karavasiloglou, and A. L. Matalas. 2017. Traditional low-alcoholic and non-alcoholic fermented beverages consumed in European countries: A neglected food group. Nutrition Research Reviews 30 (1):1-24. doi: 10.1017/ S0954422416000202.

Behera, S. S., R. C. Ray, and N. Zdolec. 2018. Lactobacillus plantarum with functional properties: An approach to increase safety and shelflife of fermented foods. BioMed Research International 2018: 9361614. doi: 10.1155/2018/9361614.

Bekkali, N. L. H., M. E. J. Bongers, M. M. Van Den Berg, O. Liem, and M. A. Benninga. 2007. The role of a probiotics mixture in the treatment of childhood constipation: A pilot study. Nutrition Journal 6 (1):17. doi: 10.1186/1475-2891-6-17.

Berdanier, C. D., J. T. Dwyer, and D. Herber. 2013. Handbook of nutrition and food. 3rd ed. Boca Raton, FL: CRC Press, Taylos and Francis Group.

Bhataya, A., C. Schmidt-Dannert, and P. C. Lee. 2009. Metabolic engineering of Pichia pastoris X-33 for lycopene production. Process Biochemistry 44 (10):1095-102. doi: 10.1016/j.procbio.2009.05.012.

Blandino, A., M. E. Al-Aseeri, S. S. Pandiella, D. Cantero, and C. Webb. 2003. Cereal-based fermented foods and beverages. Food Research International 36 (6):527-43. https://doi.org/10.1016/S09639969. (03)00009-7 doi: 10.1016/S0963-9969(03)00009-7.

Botes, A., S. D. Todorov, J. W. von Mollendorff, A. Botha, and L. M. T. Dicks. 2007. Identification of lactic acid bacteria and yeast from boza. Process Biochemistry 42 (2):267-70. doi: 10.1016/j.procbio.2006.07.015.

Bourdichon, F., S. Casaregola, C. Farrokh, J. C. Frisvad, M. L. Gerds, W. P. Hammes, J. Harnett, G. Huys, S. Laulund, A. Ouwehand, et al. 2012. Food fermentations: Microorganisms with technological beneficial use. International Journal of Food Microbiology 154 (3): 87-97. doi: 10.1016/j.ijfoodmicro.2011.12.030.

Capozzi, V., P. Russo, M. T. Dueñas, P. López, and G. Spano. 2012. Lactic acid bacteria producing B-group vitamins: A great potential for functional cereals products. Applied Microbiology and Biotechnology 96 (6):1383-94. doi: 10.1007/s00253-012-4440-2.

Castillo-Morales, M., M. D. C. Wacher-Rodarte, and H. HernándezSánchez. 2005. Preliminary studies on chorote - A traditional Mexican fermented product. World Journal of Microbiology and Biotechnology 21 (3):293-6. doi: 10.1007/s11274-004-3634-x.

Caulier, S., C. Nannan, A. Gillis, F. Licciardi, C. Bragard, and J. Mahillon. 2019. Overview of the antimicrobial compounds produced by members of the Bacillus subtilis group. Frontiers in Microbiology 10:302. doi: $10.3389 /$ fmicb.2019.00302.

Cervantes Contreras, M., and A. M. Pedroza Rodríguez. 2007. El Pulque: Características Microbiológicas y Contenido Alcohólico Mediante Espectroscopia Raman. Nova 5 (8):135. doi: 10.22490/ 24629448.382.

Cervantes-Elizarrarás, A., N. Cruz-Cansino, E. Ramírez-Moreno, V. Vega-Sánchez, N. Velázquez-Guadarrama, Q. Zafra-Rojas, and J. Piloni-Martini. 2019. In Vitro probiotic potential of lactic acid bacteria isolated from Aguamiel and Pulque and antibacterial activity against pathogens. Applied Sciences 9 (3):601. https://doi.org/10. 3390/app9030601

Chang, H.-W., K.-H. Kim, Y.-D. Nam, S. W. Roh, M.-S. Kim, C. O. Jeon, H.-M. Oh, and J.-W. Bae. 2008. Analysis of yeast and archaeal population dynamics in kimchi using denaturing gradient gel electrophoresis. International Journal of Food Microbiology 126 (1-2): 159-66. doi: 10.1016/j.ijfoodmicro.2008.05.013.

Chaves-López, C., R. Tofalo, A. Serio, A. Paparella, G. Sacchetti, and G. Suzzi. 2012. Yeasts from Colombian Kumis as source of peptides with Angiotensin I converting enzyme (ACE) inhibitory activity in milk. International Journal of Food Microbiology 159 (1):39-46. doi: 10.1016/j.ijfoodmicro.2012.07.028.

Chen, C., P. Somavat, V. Singh, and E. Gonzalez de Mejia. 2017. Chemical characterization of proanthocyanidins in purple, blue, and red maize coproducts from different milling processes and their 
anti-inflammatory properties. Industrial Crops and Products 109: 464-75. doi: 10.1016/j.indcrop.2017.08.046.

Chen, Y., Z. Wang, X. Chen, Y. Liu, H. Zhang, and T. Sun. 2010. Identification of angiotensin I-converting enzyme inhibitory peptides from koumiss, a traditional fermented mare's milk. Journal of Dairy Science 93 (3):884-92. doi: 10.3168/jds.2009-2672.

Chen, Y-s, H-c Wu, H-y Lo, W-c Lin, W-h Hsu, C-w Lin, P-y Lin, and F. Yanagida. 2012. Isolation and characterisation of lactic acid bacteria from jiang-gua (fermented cucumbers), a traditional fermented food in Taiwan. Journal of the Science of Food and Agriculture 92 (10):2069-75. doi: 10.1002/jsfa.5583.

Chettri, R., and J. P. Tamang. 2014. Functional properties of Tungrymbai and Bekang, naturally fermented soybean foods of North East India. International Journal of Fermented Foods 3 (1):87. doi: 10.5958/2321-712X.2014.01311.8.

Chi, Z., G. L. Liu, Y. Lu, H. Jiang, and Z. M. Chi. 2016. Bio-products produced by marine yeasts and their potential applications. Bioresource Technology 202:244-52. doi: 10.1016/j.biortech.2015.12.039.

Cho, S. S., L. Qi, G. C. Fahey, and D. M. Klurfeld. 2013. Consumption of cereal fiber, mixtures of whole grains and bran, and whole grains and risk reduction in type 2 diabetes, obesity, and cardiovascular disease. The American Journal of Clinical Nutrition 98 (2):594-619. doi: 10.3945/ajen.113.067629.

Chugh, B., and A. Kamal-Eldin. 2020. Bioactive compounds produced by probiotics in food products. Current Opinion in Food Science 32: 76-82. doi: 10.1016/j.cofs.2020.02.003.

Cifelli, C. J., P. D. Cotter, B. Foligne, R. Kort, G. Pasin, and A. Pihlanto 2017. Health benefits of fermented foods : microbiota and beyond ScienceDirect Health benefits of fermented foods: Microbiota and beyond. Current Opinion in Biotechnology 44 (January):94-102. doi: 10.1016/j.copbio.2016.11.010.

Collins, M. D., J. Samelis, J. Metaxopoulos, and S. Wallbanks. 1993. Taxonomic studies on some leuconostoc-like organisms from fermented sausages: Description of a new genus Weissella for the Leuconostoc paramesenteroides group of species. The Journal of Applied Bacteriology 75 (6):595-603. http://www.ncbi.nlm.nih.gov/ pubmed/8294308. doi: 10.1111/j.1365-2672.1993.tb01600.x.

Correa-Ascencio, M., I. G. Robertson, O. Cabrera-Cortés, R. CabreraCastro, and R. P. Evershed. 2014. Pulque production from fermented agave sap as a dietary supplement in Prehispanic Mesoamerica. Proceedings of the National Academy of Sciences of the United States of America 111 (39):14223-8. doi: 10.1073/pnas.1408339111.

De Mejia, E. G., and V. P. Dia. 2010. The role of nutraceutical proteins and peptides in apoptosis, angiogenesis, and metastasis of cancer cells. Cancer Metastasis Reviews 29 (3):511-28. doi: 10.1007/s10555-010-9241-4.

De Munter, J. S. L., F. B. Hu, D. Spiegelman, M. Franz, and R. M. Van Dam. 2007. Whole grain, bran, and germ intake and risk of type 2 diabetes: A prospective cohort study and systematic review. PLoS Medicine 4 (8):e261. doi: 10.1371/journal.pmed.0040261.

De Roos, J., and L. De Vuyst. 2018. Acetic acid bacteria in fermented foods and beverages. Current Opinion in Biotechnology 49:115-9. doi: 10.1016/j.copbio.2017.08.007.

Den Besten, G., K. Van Eunen, A. K. Groen, K. Venema, D. J. Reijngoud, and B. M. Bakker. 2013. The role of short-chain fatty acids in the interplay between diet, gut microbiota, and host energy metabolism. Journal of Lipid Research 54 (9):2325-40. doi: 10.1194/jlr.R036012.

Díaz-Ruiz, G., J. P. Guyot, F. Ruiz-Teran, J. Morlon-Guyot, and C. Wacher. 2003. Microbial and physiological characterization of weakly amylolytic but fast-growing lactic acid bacteria: A functional role in supporting microbial diversity in pozol, a Mexican fermented maize beverage. Applied and Environmental Microbiology 69 (8): 4367-74. doi: 10.1128/aem.69.8.4367-4374.2003.

Dogan, M., and H. Ozpinar. 2017. Investigation of probiotic features of bacteria isolated from some food products. Kafkas Üniversitesi Veteriner Fakültesi Dergisi 23 (4):555-62. 10.9775/kvfd.2016.17273.

Erten, H., H. Tanguler, and A. Canbaş. 2008. A traditional Turkish lactic acid fermented beverage: Shalgam (Salgam). Food Reviews International 24 (3):352-9. doi: 10.1080/87559120802089324.

Escalante, A., M. Elena Rodriguez, A. Martinez, A. Lopez-Munguia, F. Bolivar, and G. Gosset. 2004. Characterization of bacterial diversity in Pulque, a traditional Mexican alcoholic fermented beverage, as determined by $16 \mathrm{~S}$ rDNA analysis. FEMS Microbiology Letters 235 (2):273-9. doi: 10.1111/j.1574-6968.2004.tb09599.x.

Escalante, A., M. Giles Gomez, G. Hernandez, M. Cordova Aguilar, A. Lopez Munguia, G. Gosset, and F. Bolivar. 2008. Analysis of bacterial community during the fermentation of pulque, a traditional Mexican alcoholic beverage, using a polyphasic approach. International Journal of Food Microbiology 124 (2):126-34. doi: 10. 1016/j.ijfoodmicro.2008.03.003.

Escalante, A., D. R. López Soto, J. E. Velázquez Gutiérrez, M. GilesGómez, F. Bolívar, and A. López-Munguía. 2016. Pulque, a traditional Mexican alcoholic fermented beverage: Historical, microbiological, and technical aspects. Frontiers in Microbiology 7:1026. doi: 10.3389/fmicb.2016.01026.

Escalante, A., C. Wacher, and A. Farrés. 2001. Lactic acid bacterial diversity in the traditional Mexican fermented dough pozol as determined by $16 \mathrm{~S}$ rDNA sequence analysis. International Journal of Food Microbiology 64 (1-2):21-31. doi: 10.1016/S0168-1605(00)00428-1.

Even, S., S. Leroy, C. Charlier, N. B. Zakour, J.-P. Chacornac, I. Lebert, E. Jamet, M.-H. Desmonts, E. Coton, S. Pochet, et al. 2010. Low occurrence of safety hazards in coagulase negative staphylococci isolated from fermented foodstuffs. International Journal of Food Microbiology 139 (1-2):87-95. doi: 10.1016/j.ijfoodmicro.2010.02.019.

Falchero, L., G. Lombardi, A. Gorlier, M. Lonati, M. Odoardi, and A. Cavallero. 2010. Variation in fatty acid composition of milk and cheese from cows grazed on two alpine pastures. Dairy Science \& Technology 90 (6):657-72. doi: 10.1051/dst/2010035.

Farhad, M., K. Kailasapathy, and J. Tamang. 2010. Health aspects of fermented foods. In Fermented foods and beverages of the world, eds. J. P. Tamang and K. Kailasapathy, 391-414. New York: CRC Press. 10.1201/EBK1420094954-c15.

Fitzgerald, R. J., and B. A. Murray. 2006. Bioactive peptides and lactic fermentations. International Journal of Dairy Technology 59 (2): 118-25. doi: 10.1111/j.1471-0307.2006.00250.x.

Franciosa, I., V. Alessandria, P. Dolci, K. Rantsiou, and L. Cocolin. 2018. Sausage fermentation and starter cultures in the era of molecular biology methods. International Journal of Food Microbiology 279:26-32. doi: 10.1016/j.ijfoodmicro.2018.04.038.

Freire, A. L., C. L. Ramos, P. N. da Costa Souza, M. G. B. Cardoso, and R. F. Schwan. 2017. Nondairy beverage produced by controlled fermentation with potential probiotic starter cultures of lactic acid bacteria and yeast. International Journal of Food Microbiology 248: 39-46. doi: 10.1016/j.ijfoodmicro.2017.02.011.

Gaggia, F., D. Di Gioia, L. Baffoni, and B. Biavati. 2011. The role of protective and probiotic cultures in food and feed and their impact in food safety. Trends in Food Science and Technology 22(SUPPL. 1): S58-S66. 10.1016/j.tifs.2011.03.003.

Gaisawat, M. B., M. M. Iskandar, C. W. MacPherson, T. A. Tompkins, and S. Kubow. 2019. Probiotic supplementation is associated with increased antioxidant capacity and copper chelation in C. difficileinfected fecal water. Nutrients 11 (9):2007. doi: 10.3390/nu11092007.

García, C., M. Rendueles, and M. Díaz. 2019. Liquid-phase food fermentations with microbial consortia involving lactic acid bacteria: A review. Food Research International 119:207-20. doi: 10.1016/ j.foodres.2019.01.043.

Ghosh, K., M. Ray, A. Adak, S. K. Halder, A. Das, A. Jana, S. Parua Mondal, C. Vágvölgyi, P. K. Das Mohapatra, B. R. Pati, et al. 2015. Role of probiotic Lactobacillus fermentum KKL1 in the preparation of a rice based fermented beverage. Bioresource Technology 188: 161-8. doi: 10.1016/j.biortech.2015.01.130.

Gill, P. A., M. C. van Zelm, J. G. Muir, and P. R. Gibson. 2018. Short chain fatty acids as potential therapeutic agents in human gastrointestinal and inflammatory disorders. Alimentary Pharmacology and Therapeutics 48:15-34. 10.1111/apt.14689.

Giles-Gómez, M., J. G. Sandoval García, V. Matus, I. Campos Quintana, F. Bolívar, and A. Escalante. 2016. In vitro and in vivo probiotic assessment of Leuconostoc mesenteroides P45 isolated from pulque, a Mexican traditional alcoholic beverage. SpringerPlus 5 (1):708. https://doi.org/10.1186/s40064-016-2370-7 
Giudici, P., L. De Vero, and M. Gullo. 2017. Acetic acid bacteria: Fundamentals and food applications. In Vinegars, ed. I. Y. Sengun, 261-87. Boca Raton, FL: CRC Press.

Greppi, A., K. Rantsiou, W. Padonou, J. Hounhouigan, L. Jespersen, M. Jakobsen, and L. Cocolin. 2013. Determination of yeast diversity in ogi, mawè, gowé and tchoukoutou by using culture-dependent and -independent methods. International Journal of Food Microbiology 165 (2):84-8. doi: 10.1016/j.ijfoodmicro.2013.05.005.

Grosu-Tudor, S. S., and M. Zamfir. 2013. Functional properties of lactic acid bacteria isolated from Romanian fermented vegetables. Food Biotechnology 27 (3):235-48. doi: 10.1080/08905436.2013.811082.

Güzel-Seydim, Z. B., A. C. Seydim, A. K. Greene, and A. B. Bodine. 2000. Determination of organic acids and volatile flavor substances in Kefir during fermentation. Journal of Food Composition and Analysis 13 (1):35-43. doi: 10.1006/jfca.1999.0842.

Han, Y.-Z., C.-C. Zhou, Y.-Y. Xu, J.-X. Yao, Z. Chi, Z.-M. Chi, and G.L. Liu. 2017. High-efficient production of fructo-oligosaccharides from inulin by a two-stage bioprocess using an engineered Yarrowia lipolytica strain. Carbohydrate Polymers 173:592-9. doi: 10.1016/j. carbpol.2017.06.043.

Hancioğlu, Ö., and M. Karapinar. 1997. Microflora of Boza, a traditional fermented Turkish beverage. International Journal of Food Microbiology 35 (3):271-4. https://doi.org/10.1016/S0168-1605. (96)01230-5 doi: 10.1016/S0168-1605(96)01230-5.

Handa, S., and N. Sharma. 2016. In vitro study of probiotic properties of Lactobacillus plantarum F22 isolated from chhang - A traditional fermented beverage of Himachal Pradesh. Journal of Genetic Engineering \& Biotechnology 14 (1):91-7. doi: 10.1016/j.jgeb.2016.08.001.

Hasan, T., G. Gulden, and E. Huseyin. 2014. Influence of addition of different amounts of black carrot (Daucus carota) on shalgam quality. Journal of Food Agricultural \& Environment 12:60-5.

Hayes, M., R. P. Ross, G. F. Fitzgerald, C. Hill, and C. Stanton. 2006. Casein-derived antimicrobial peptides generated by Lactobacillus acidophilus DPC6026. Applied and Environmental Microbiology 72 (3):2260-4. doi: 10.1128/AEM.72.3.2260-2264.2006.

He, H. L., D. Liu, and C. B. Ma. 2013. Review on the Angiotensin-IConverting Enzyme (ACE) inhibitor peptides from marine proteins. Applied Biochemistry and Biotechnology 169 (3):738-49. doi: 10. 1007/s12010-012-0024-y.

Hittinger, C. T., J. L. Steele, and D. S. Ryder. 2018. Diverse yeasts for diverse fermented beverages and foods. Current Opinion in Biotechnology 49:199-206. doi: 10.1016/j.copbio.2017.10.004.

Holzapfel, W. H. 2002. Appropriate starter culture technologies for small-scale fermentation in developing countries. International Journal of Food Microbiology 75 (3):197-212. https://doi.org/10. 1016/S0168-1605. doi: 10.1016/S0168-1605(01)00707-3.

Holzapfel, W. H., and U. Schillinger. 2002. Introduction to pre- and probiotics. Food Research International 35 (2-3):109-16. doi: 10. 1016/S0963-9969(01)00171-5.

Hugenholtz, J. 2013. Traditional biotechnology for new foods and beverages. Current Opinion in Biotechnology 24 (2):155-9. doi: 10.1016/ j.copbio.2013.01.001.

Hur, J. W., H. H. Hyun, Y. R. Pyun, T. S. Kim, I. H. Yeo, and H. D. Paik. 2000. Identification and partial characterization of lacticin $\mathrm{BH}$, a bacteriocin produced by Lactococcus lactis $\mathrm{BH} 5$ isolated from Kimchi. Journal of Food Protection 63 (12):1707-12. doi: 10.4315/ 0362-028x-63.12.1707.

Ichimura, T., J. Hu, D. Q. Aita, and S. Maruyama. 2003. Angiotensin Iconverting enzyme inhibitory activity and insulin secretion stimulative activity of fermented fish sauce. Journal of Bioscience and Bioengineering 96 (5):496-9. doi: 10.1016/S1389-1723(03)70138-8.

Johanningsmeier, S., R. F. McFeeters, H. P. Fleming, and R. L. Thompson. 2007. Effects of leuconostoc mesenteroides starter culture on fermentation of cabbage with reduced salt concentrations. Journal of Food Science 72 (5):M166-M172. doi: 10.1111/j.17503841.2007.00372.x.

Kammerer, D., R. Carle, and A. Schieber. 2003. Detection of peonidin and pelargonidin glycosides in black carrots (Daucus carota ssp. sativus var. atrorubens Alef.) by high-performance liquid chromatography/ electrospray ionization mass spectrometry. Rapid Communications in Mass Spectrometry: RCM 17 (21):2407-12. doi: 10.1002/rcm.1212.

Kammerer, D., R. Carle, and A. Schieber. 2004. Quantification of anthocyanins in black carrot extracts (Daucus carota ssp. sativus var. atrorubens Alef.) and evaluation of their color properties. European Food Research and Technology 219 (5):479-86. doi: 10.1007/s00217-004-0976-4.

Kancabaş, A., and S. Karakaya. 2013. Angiotensin-converting enzyme (ACE)-inhibitory activity of boza, a traditional fermented beverage. Journal of the Science of Food and Agriculture 93 (3):641-5. doi: 10. $1002 /$ jsfa.5883.

Kariluoto, S., M. Aittamaa, M. Korhola, H. Salovaara, L. Vahteristo, and V. Piironen. 2006. Effects of yeasts and bacteria on the levels of folates in rye sourdoughs. International Journal of Food Microbiology 106 (2):137-43. doi: 10.1016/j.ijfoodmicro.2005.06.013.

Katan, M. B., M. V. Boekschoten, W. E. Connor, R. P. Mensink, J. Seidell, B. Vessby, and W. Willett. 2009. Which are the greatest recent discoveries and the greatest future challenges in nutrition? European Journal of Clinical Nutrition 63 (1):2-10. doi: 10.1038/sj. ejcn.1602923.

Kaushik, J. K., A. Kumar, R. K. Duary, A. K. Mohanty, S. Grover, and V. K. Batish. 2009. Functional and probiotic attributes of an indigenous isolate of Lactobacillus plantarum. PLoS One 4 (12):e8099. doi: 10.1371/journal.pone.0008099.

Khan, H., S. Flint, and P. L. Yu. 2010. Enterocins in food preservation. International Journal of Food Microbiology 141 (1-2):1-10. doi: 10. 1016/j.ijfoodmicro.2010.03.005.

Khedkar, C. D., S. D. Kalyankar, and S. S. Deosarkar. 2016. Fermented foods: Fermented milks. In Encyclopedia of food and health, 661-7. Oxford: Academic Press. 10.1016/B978-0-12-384947-2.00286-5.

King, W. Q., S. P. Ping, S. Cheng Shih, C. T. Rong, and W. Que King 2012. Effect of isoflavone aglycone content and antioxidation activity in natto by various cultures of Bacillus subtilis during the fermentation period. Journal of Nutrition \& Food Sciences 02 (07):1-6. doi: 10.4172/2155-9600.1000153.

Koebnick, C., I. Wagner, P. Leitzmann, U. Stern, and H. J. F. Zunft. 2003. Probiotic beverage containing Lactobacillus casei Shirota improves gastrointestinal symptoms in patients with chronic constipation. Canadian Journal of Gastroenterology 17 (11):655-9. doi: 10. 1155/2003/654907.

Kong, F., L. Wang, H. Gao, and H. Chen. 2020. Process of steam explosion assisted superfine grinding on particle size, chemical composition and physico-chemical properties of wheat bran powder. Powder Technology 371:154-60. doi: 10.1016/j.powtec.2020.05.067.

Kong, J. M., L. S. Chia, N. K. Goh, T. F. Chia, and R. Brouillard. 2003. Analysis and biological activities of anthocyanins. Phytochemistry 64 (5):923-33. doi: 10.1016/S0031-9422(03)00438-2.

Korhonen, H., and A. Pihlanto. 2006. Bioactive peptides: Production and functionality. International Dairy Journal 16 (9):945-60. doi: 10. 1016/j.idairyj.2005.10.012.

Kort, R., N. Westerik, L. Mariela Serrano, F. P. Douillard, W. Gottstein, I. M. Mukisa, C. J. Tuijn, L. Basten, B. Hafkamp, W. C. Meijer, et al. 2015. A novel consortium of Lactobacillus rhamnosus and Streptococcus thermophilus for increased access to functional fermented foods. Microbial Cell Factories 14 (1):195. doi: 10.1186/ s12934-015-0370-X.

Kumar, N., and N. Goel. 2019. Phenolic acids: Natural versatile molecules with promising therapeutic applications. Biotechnology Reports 24:e00370. doi: 10.1016/j.btre.2019.e00370.

Kumar, N., S. Gupta, T. Chand Yadav, V. Pruthi, P. Kumar Varadwaj, and N. Goel. 2019. Extrapolation of phenolic compounds as multitarget agents against cancer and inflammation. Journal of Biomolecular Structure and Dynamics 37 (9):2355-69. doi: 10.1080/ 07391102.2018.1481457.

Kurtzman, C. P., J. W. Fell, and T. Boekhout. 2011. The yeasts: A taxonomic study. Burlington: Elsevier Science.

Cíntia, L., G. Euziclei, V. Gilberto, G. Patrícia, and F. R. Souza Eustáquio. 2010. Determination of dynamic characteristcs of microbiota in a fermented beverage produced by Brazilian Amenrindians using culture-dependent an culture. Independent methods. International Journal of Food Microbiology 140:225-13. 
Lambrechts, M. G., and I. S. Pretorius. 2019. Yeast and its importance to wine aroma - A review. South African Journal of Enology \& Viticulture 21 (1):97-129. doi: 10.21548/21-1-3560.

Lappe-Oliveras, P., R. Moreno-Terrazas, J. Arrizon-Gaviño, T. HerreraSuarez, A. Garcia-Mendoza, and A. Gschaedler-Mathis. 2008. Yeasts associated with the production of Mexican alcoholic nondistilled and distilled Agave beverages. FEMS Yeast Research 8 (7):1037-52. doi: 10.1111/j.1567-1364.2008.00430.x.

Lee, D., L. Albenberg, C. Compher, R. Baldassano, D. Piccoli, J. D. Lewis, and G. D. Wu. 2015. Diet in the pathogenesis and treatment of inflammatory bowel diseases. Gastroenterology 148 (6):1087-106. doi: 10.1053/j.gastro.2015.01.007.

Lee, S., Y. Hwang, M. Kim, M. Chung, and Y.-S. Kim. 2019. Comparison of volatile and nonvolatile compounds in rice fermented by different lactic acid bacteria. Molecules 24 (6):1183. doi: 10.3390/molecules24061183.

López-Hernández, M., M. E. Rodríguez-Alegría, A. López-Munguía, and C. Wacher. 2018. Evaluation of xylan as carbon source for Weissella spp., a predominant strain in pozol fermentation. LWT 89: 192-7. doi: 10.1016/j.lwt.2017.10.030.

Lu, Y., S. D. Putra, and S.-Q. Liu. 2018. A novel non-dairy beverage from durian pulp fermented with selected probiotics and yeast. International Journal of Food Microbiology 265:1-8. doi: 10.1016/j. ijfoodmicro.2017.10.030.

Lynch, K. M., E. Zannini, S. Wilkinson, L. Daenen, and E. K. Arendt. 2019. Physiology of acetic acid bacteria and their role in vinegar and fermented beverages. Comprehensive Reviews in Food Science and Food Safety 18 (3):587-625. doi: 10.1111/1541-4337.12440.

Malimas, T., H. Thi Lan Vu, Y. Muramatsu, P. Yukphan, S. Tanasupawat, and Y. Yamada (2018). Systematics of acetic acid bacteria. In Acetic acid bacteria, 3-43. Boca Raton, FL: CRC Press. 10. 1201/9781315153490-2.

Malli, T. P., and S. C. Tripathi. 2015. Millets the nutrimental potent ethno-medicinal grasses: A review. World Journal of Pharmaceutical Research 5 (2):495-520.

Markowiak, P., and K. Śliżewska. 2017. Effects of probiotics, prebiotics, and synbiotics on human health. Nutrients 9 (9):1021. 10.3390/nu9091021.

Matsushita, K., and Matsutani, M. (2016). Distribution, evolution, and physiology of oxidative fermentation. In Acetic acid bacteria: Ecology and physiology, eds. K. Matsushita, H. Toyama, N. Tonouchi, and A. Okamoto-Kainuma, 159-187. New York: Springer.

McDougall, G. J., I. M. Morrison, D. Stewart, and J. R. Hillman. 1996. Plant cell walls as dietary fibre: Range, structure, processing and function. Journal of the Science of Food and Agriculture 70 (2):133-50. doi: 10.1002/(SICI)1097-0010(199602)70:2<133::AID-JSFA495>3.0.CO;2-4.

Méndez-Albores, J. A., G. Arámbula-Villa, M. G. Loarca-Piña, J. González-Hernández, E. Castaño-Tostado, and E. Moreno-Martínez. 2004. Aflatoxins' fate during the nixtamalization of contaminated maize by two tortilla-making processes. Journal of Stored Products Research 40 (1):87-94. https://doi.org/10.1016/S0022-474X. (02)00080-2 doi: 10.1016/S0022-474X(02)00080-2.

Meyer, J., U. Bütikofer, B. Walther, D. Wechsler, and R. Sieber. 2009. Hot topic: Changes in angiotensin-converting enzyme inhibition and concentrations of the tripeptides Val-Pro-Pro and Ile-Pro-Pro during ripening of different Swiss cheese varieties. Journal of Dairy Science 92 (3):826-36. doi: 10.3168/jds.2008-1531.

Mishra, V., C. Shah, N. Mokashe, R. Chavan, H. Yadav, and J. Prajapati. 2015. Probiotics as potential antioxidants: A systematic review. Journal of Agricultural and Food Chemistry 63 (14):3615-26. doi: $10.1021 /$ jf506326t.

Mitra, S., P. K. Chakrabartty, and S. R. Biswas. 2010. Potential production and preservation of dahi by Lactococcus lactis W8, a nisin-producing strain. LWT - Food Science and Technology 43 (2):337-42. doi: 10.1016/j.lwt.2009.08.013.

Mizgier, P., A. Z. Kucharska, A. Sokół-Łe ôtowska, J. Kolniak-Ostek, M. Kidonb, K. Kidonb, and I. Fecka. 2015. Characterization of phenolic compounds and antioxidant and anti-inflammatory properties of red cabbage and purple carrot extracts. Journal of Functional Foods 21:133-46. 10.1016/j.jff.2015.12.004.
Mohammed, Y., B. Lee, Z. Kang, and G. Du. 2014. Capability of Lactobacillus reuteri to produce an active form of vitamin B12 under optimized fermentation conditions. Journal of Academia and Industrial Research 2: 617-21. https://www.researchgate.net/publication/274951979

Moktan, B., J. Saha, and P. K. Sarkar. 2008. Antioxidant activities of soybean as affected by Bacillus-fermentation to kinema. Food Research International 41 (6):586-93. doi: 10.1016/j.foodres.2008.04.003.

Montel, M. C., S. Buchin, A. Mallet, C. Delbes-Paus, D. A. Vuitton, N. Desmasures, and F. Berthier. 2014. Traditional cheeses: Rich and diverse microbiota with associated benefits. International Journal of Food Microbiology 177:136-54. doi: 10.1016/j.ijfoodmicro.2014.02.019.

Morales de León, J., H. Bourges, and M. E. Camacho. 2005. Amino acid composition of some Mexican foods. Archivos Latinoamericanos de Nutricion 55 (2):172-85.

Moran, S., K. Robertson, F. Paradisi, D. K. Rai, and C. D. Murphy. 2010. Production of lipopeptides in Bacillus sp. CS93 isolated from Pozol. FEMS Microbiology Letters 304 (1):69-73. doi: 10.1111/j.15746968.2009.01882.x.

$\mathrm{Mu}, \mathrm{Z}$., X. Yang, and H. Yuan. 2012. Detection and identification of wild yeast in Koumiss. Food Microbiology 31 (2):301-8. doi: 10. 1016/j.fm.2012.04.004.

Mugula, J. K., S. A. M. Nnko, J. A. Narvhus, and T. Sørhaug. 2003. Microbiological and fermentation characteristics of togwa, a Tanzanian fermented food. International Journal of Food Microbiology 80 (3):187-99. doi: 10.1016/S0168-1605(02)00141-1.

Nai, C., and V. Meyer. 2018. From axenic to mixed cultures: Technological advances accelerating a paradigm shift in microbiology. Trends in Microbiology 26 (6):538-54. doi: 10.1016/j.tim.2017.11.004.

Nobre, C., M. Â. Cerqueira, L. R. Rodrigues, A. A. Vicente, and J. A. Teixeira. 2015. Production and extraction of polysaccharides and oligosaccharides and their use as new food additives. In Industrial biorefineries and white biotechnology, 653-679. Amsterdam: Elsevier. 10.1016/B978-0-444-63453-5.00021-5.

Nuraida, L., M. C. Wacher, and J. D. Owens. 1995. Microbiology of pozol, a Mexican fermented maize dough. World Journal of Microbiology \& Biotechnology 11 (5):567-71. doi: 10.1007/BF00286375.

Odunfa, S. A., and O. B. Oyewole. 1998. African fermented foods. In Microbiology of fermented foods, 713-52. London: Springer. 10.1007/ 978-1-4613-0309-1_23.

Oguntoyinbo, F. A., P. Tourlomousis, M. J. Gasson, and A. Narbad. 2011. Analysis of bacterial communities of traditional fermented West African cereal foods using culture independent methods. International Journal of Food Microbiology 145 (1):205-10. doi: 10. 1016/j.ijfoodmicro.2010.12.025.

Olasupo, N. A., S. A. Odunfa, O. S. Obayori, S. A. Odunfa, and O. S. Obayori. 2010. Ethnic African fermented foods. In Fermented foods and beverages of the world, 335-64. Boca Raton: CRC Press. 10. 1201/EBK1420094954-16.

Oyewole, O. B. 1997. Lactic fermented foods in Africa and their benefits. Food Control 8 (5-6):289-97. doi: 10.1016/S0956-7135(97)00075-3.

Panghal, A., S. Janghu, K. Virkar, Y. Gat, V. Kumar, and N. Chhikara. 2018. Potential non-dairy probiotic products - A healthy approach. Food Bioscience 21:80-9. doi: 10.1016/j.fbio.2017.12.003.

Papadimitriou, C. G., A. Vafopoulou-Mastrojiannaki, S. V. Silva, A. M. Gomes, F. X. Malcata, and E. Alichanidis. 2007. Identification of peptides in traditional and probiotic sheep milk yoghurt with angiotensin I-converting enzyme (ACE)-inhibitory activity. Food Chemistry 105 (2):647-56. doi: 10.1016/j.foodchem.2007.04.028.

Patel, A., J. B. Prajapati, O. Holst, and A. Ljungh. 2014. Determining probiotic potential of exopolysaccharide producing lactic acid bacteria isolated from vegetables and traditional Indian fermented food products. Food Bioscience 5:27-33. doi: 10.1016/j.fbio.2013.10.002.

Petruzzi, L., M. Rosaria Corbo, M. Sinigaglia, and A. Bevilacqua. 2016. Brewer's yeast in controlled and uncontrolled fermentations, with a focus on novel, nonconventional, and superior strains. Food Reviews International 32 (4):341-63. doi: 10.1080/87559129.2015.1075211.

Peyer, L. C., E. Zannini, and E. K. Arendt. 2016. Lactic acid bacteria as sensory biomodulators for fermented cereal-based beverages. Trends in Food Science and Technology 54:17-25. 10.1016/j.tifs.2016.05.009. 
Phister, T. G., D. J. O'Sullivan, and L. L. McKay. 2004. Identification of bacilysin, chlorotetaine, and iturin A produced by Bacillus sp. Strain CS93 isolated from Pozol, a Mexican fermented maize dough. Applied and Environmental Microbiology 70 (1):631-4. doi: 10.1128/ aem.70.1.631-634.2004.

Piwowarek, K., E. Lipińska, E. Hać-Szymańczuk, M. Kieliszek, and I. Ścibisz. 2018. Propionibacterium spp.-source of propionic acid, vitamin B12, and other metabolites important for the industry. Applied Microbiology and Biotechnology 102 (2):515-38. doi: 10. 1007/s00253-017-8616-7.

Quero, J. C. J. 2000. Bebidas y dulces tradicionales de Tabasco, Cocina Indigena y popular. Consejo Nacional para la Cultura y las Artes. ISBN 13: 9789701851241.

Quirós, A., B. Hernández-Ledesma, M. Ramos, L. Amigo, and I. Recio. 2005. Angiotensin-converting enzyme inhibitory activity of peptides derived from caprine kefir. Journal of Dairy Science 88 (10):3480-7. doi: $10.3168 /$ jds.S0022-0302(05)73032-0.

Racaño, M. R. 2000. Ignacio Torres Adalid y la industria pulquera Mario Ramírez Rancaño - Google Libros.

Rai, A. K., and K. Jeyaram. (2017). Role of yeasts in food fermentation. In Yeast diversity in human welfare, 83-113. Singapore: Springer. 10. 1007/978-981-10-2621-8_4

Rai, A. K., R. Kumari, S. Sanjukta, and D. Sahoo. 2016. Production of bioactive protein hydrolysate using the yeasts isolated from soft chhurpi. Bioresource Technology 219:239-45. doi: 10.1016/j.biortech. 2016.07.129.

Ramos, C. L., E. G. de Almeida, A. L. Freire, and R. Freitas Schwan. 2011. Diversity of bacteria and yeast in the naturally fermented cotton seed and rice beverage produced by Brazilian Amerindians. Food Microbiology 28 (7):1380-6. doi: 10.1016/j.fm.2011.06.012.

Ramos, C. L., and R. F. Schwan. 2017. Technological and nutritional aspects of indigenous Latin America fermented foods. Current Opinion in Food Science 13:97-102. doi: 10.1016/j.cofs.2017.07.001.

Rehaiem, A., B. Martínez, M. Manai, and A. Rodríguez. 2010. Production of enterocin A by Enterococcus faecium MMRA isolated from 'Rayeb', a traditional Tunisian dairy beverage. Journal of Applied Microbiology 108 (5):1685-93. doi: 10.1111/j.1365-2672.2009. 04565.x.

Ribéreau-Gayon, P. 2000. The microbiology of wine and vinifications.

Rodriguez, A., T. Strucko, S. G. Stahlhut, M. Kristensen, D. K. Svenssen, J. Forster, J. Nielsen, and I. Borodina. 2017. Metabolic engineering of yeast for fermentative production of flavonoids. Bioresource Technology 245 (Pt B):1645-54. doi: 10.1016/j.biortech. 2017.06.043.

Rousseau, S., C. Kyomugasho, M. Celus, M. E. G. Hendrickx, and T. Grauwet. 2019. Critical reviews in food science and nutrition barriers impairing mineral bioaccessibility and bioavailability in plantbased foods and the perspectives for food processing. Critical Reviews in Food Science and Nutrition 60:826-843. doi: 10.1080/ 10408398.2018.1552243.

Roy, C. C., C. L. Kien, L. Bouthillier, and E. Levy. 2006. Short-chain fatty acids: Ready for prime time? Nutrition in Clinical Practice 21 (4):351-66. doi: 10.1177/0115426506021004351.

Sáez, G. D., L. Flomenbaum, and G. Zárate. 2018. Lactic acid bacteria from Argentinean fermented foods: Isolation and characterization for their potential use as starters for fermentation of vegetables. Food Technology and Biotechnology 56 (3):398-410. doi: 10.17113/ ftb.56.03.18.5631.

Salmerón, I. 2017. Fermented cereal beverages: From probiotic, prebiotic and synbiotic towards Nanoscience designed healthy drinks. Letters in Applied Microbiology 65 (2):114-24. doi: 10.1111/lam.12740.

Samet-Bali, O., I. Felfoul, R. Lajnaf, H. Attia, and M. A. Ayadi. 2017. Enumeration and identification of microflora in "Leben", a traditional Tunisian dairy beverage. International Food Research Journal 24:927-932.

Sanalibaba, P., and G. A. Cakmak. 2016. Exopolysaccharides production by lactic acid bacteria. Applied Microbiology 107(2):56-64. doi: 10.4172/2471-9315.1000115.

Sanchez-Marroquin, A., and P. H. Hope. 1953. Agave juice, fermentation and chemical composition studies of some species. Journal of
Agricultural and Food Chemistry 1 (3):246-9. doi: 10.1021/ jf60003a007.

Saulnier, L., P. E. Sado, G. Branlard, G. Charmet, and F. Guillon. 2007. Wheat arabinoxylans: Exploiting variation in amount and composition to develop enhanced varieties. Journal of Cereal Science 46 (3): 261-81. doi: 10.1016/j.jcs.2007.06.014.

Septembre-Malaterre, A., F. Remize, and P. Poucheret. 2018. Fruits and vegetables, as a source of nutritional compounds and phytochemicals: Changes in bioactive compounds during lactic fermentation. Food Research International (Ottawa, Ont.) 104:86-99. doi: 10.1016/ j.foodres.2017.09.031

Settanni, L., P. Barbaccia, A. Bonanno, M. Ponte, R. Di Gerlando, E. Franciosi, A. Di Grigoli, and R. Gaglio. 2020. Evolution of indigenous starter microorganisms and physicochemical parameters in spontaneously fermented beef, horse, wild boar and pork salamis produced under controlled conditions. Food Microbiology 87:103385. doi: $10.1016 /$ j.fm.2019.103385.

Shin, M. S., S. K. Han, J. S. Ryu, K. S. Kim, and W. K. Lee. 2008. Isolation and partial characterization of a bacteriocin produced by Pediococcus pentosaceus K23-2 isolated from Kimchi. Journal of Applied Microbiology 105 (2):331-9. doi: 10.1111/j.1365-2672.2008.03770.x.

Simova, E., D. Beshkova, A. Angelov, T. Hristozova, G. Frengova, and Z. Spasov. 2002. Lactic acid bacteria and yeasts in kefir grains and kefir made from them. Journal of Industrial Microbiology \& Biotechnology 28 (1):1-6. doi: 10.1038/sj/jim/7000186.

Sindhu, S. C., and N. Khetarpaul. 2002. Effect of probiotic fermentation on antinutrients and in vitro protein and starch digestibilities of indigenously developed RWGT food mixture. Nutrition and Health 16 (3):173-81. doi: 10.1177/026010600201600303.

Siriwardhana, N., N. S. Kalupahana, M. Cekanova, M. LeMieux, B. Greer, and N. Moustaid-Moussa. 2013. Modulation of adipose tissue inflammation by bioactive food compounds. The Journal of Nutritional Biochemistry 24 (4):613-23. doi: 10.1016/j.jnutbio.2012.12.013.

Siró, I., E. Kápolna, B. Kápolna, and A. Lugasi. 2008. Functional food. Product development, marketing and consumer acceptance-A review. Appetite 51 (3):456-67. doi: 10.1016/j.appet.2008.05.060.

Siroli, L., F. Patrignani, D. I. Serrazanetti, G. Tabanelli, C. Montanari, F. Gardini, and R. Lanciotti. 2015. Lactic acid bacteria and natural antimicrobials to improve the safety and shelf-life of minimally processed sliced apples and lamb's lettuce. Food Microbiology 47: 74-84. doi: 10.1016/j.fm.2014.11.008.

Smid, E. J., and M. Kleerebezem. 2014. Production of aroma compounds in lactic fermentations. Annual Review of Food Science and Technology 5 (1):313-26. doi: 10.1146/annurev-food-030713-092339.

Smid, E. J., and C. Lacroix. 2013. Microbe-microbe interactions in mixed culture food fermentations. Current Opinion in Biotechnology 24 (2):148-54. doi: 10.1016/j.copbio.2012.11.007.

Soleymanzadeh, N., S. Mirdamadi, and M. Kianirad. 2016. Antioxidant activity of camel and bovine milk fermented by lactic acid bacteria isolated from traditional fermented camel milk (Chal). Dairy Science \& Technology 96 (4):443-57. doi: 10.1007/s13594-016-0278-1.

Soni, S. K., D. K. Sandhu, K. S. Vilkhu, and N. Kamra. 1986. Microbiological studies on Dosa fermentation. Food Microbiology 3 (1):45-53. doi: 10.1016/S0740-0020(86)80025-9.

Soret, R., J. Chevalier, P. De Coppet, G. Poupeau, P. Derkinderen, J. P. Segain, and M. Neunlist. 2010. Short-chain fatty acids regulate the enteric neurons and control gastrointestinal motility in rats. Gastroenterology 138 (5):1772-82. doi: 10.1053/j.gastro.2010.01.053.

Spitaels, F., A. D. Wieme, M. Janssens, M. Aerts, A. Van Landschoot, L. De Vuyst, and P. Vandamme. 2015. The microbial diversity of an industrially produced lambic beer shares members of a traditionally produced one and reveals a core microbiota for lambic beer fermentation. Food Microbiology 49:23-32. doi: 10.1016/j.fm.2015.01.008.

Steinkraus, K. H. 1996. Handbook of indigenous fermented food. In Studies of outh American chichi, ed. K. H. Steinkraus, 402-6. New York: Marcel Dekker, Inc.

Steinkraus, K. H. 2004. Industrialization of indigenous fermented foods, revised and expanded - Google Libros. Accessed December 30, 2019, https://books.google.pt/books?hl=es\&lr=\&id=WfjPq9df TuMC\&oi=fnd\&pg=PR3\&dq=Steinkraus,K.H.(2004).+Industrialization+ 
Indigenous+Fermented+Foods.+New+York,NY:Marcel+Dekker,Inc.\& ots=ID5V4u-N1A\&sig=8tVkxOIZgOfC7tee23d6yVlw7ZU\&redir_esc= $\mathrm{y} \# \mathrm{v}=$ onepage \&q\& $\mathrm{f}=$ false

Tamang, J. P., and Fleet, G. H. (2009). Yeasts diversity in fermented foods and beverages. In Yeasts biotechnology: Diversity and applications, eds. T. Satyanarayana and G. Kunze. New York: Springer.

Tamang, J. P., and S. Nikkuni. 1996. Selection of starter cultures for the production of kinema, a fermented soybean food of the Himalaya. World Journal of Microbiology \& Biotechnology 12 (6): 629-35. doi: 10.1007/BF00327727.

Tamang, J., and S. Thapa. 2006. Fermentation dynamics during production of Bhaati Jaanr, a traditional fermented rice beverage of the Eastern Himalayas. Food Biotechnology 20 (3):251-61. doi: 10.1080/ 08905430600904476.

Tamang, J., N. Thapa, B. Tamang, A. Rai, and R. Chettri. 2015. Microorganisms in fermented foods and beverages. In Health benefits of fermented foods and beverages, 1-110. New York: CRC Press. 10.1201/b18279-2.

Tamang, J. P., K. Watanabe, and W. H. Holzapfel. 2016. Review: Diversity of microorganisms in global fermented foods and beverages. Frontiers in Microbiology 7 (MAR):377. doi: 10.3389/fmicb. 2016.00377.

Tamang, J. P., D.-H. Shin, S.-J. Jung, and S.-W. Chae. 2016. Functional properties of microorganisms in fermented foods. Frontiers in Microbiology 7:578. doi: 10.3389/fmicb.2016.00578.

Tamang, J. P., and K. Kailasapathy. 2010. Fermented foods and beverages of the world. Boca Raton: CRC Press/Taylor \& Francis. https:// www.crcpress.com/Fermented-Foods-and-Beverages-of-the-World/ Tamang-Kailasapathy/p/book/9781420094954

Tamang, J. P., B. Tamang, U. Schillinger, C. Guigas, and W. H. Holzapfel. 2009. Functional properties of lactic acid bacteria isolated from ethnic fermented vegetables of the Himalayas. International Journal of Food Microbiology 135 (1):28-33. doi: 10.1016/j.ijfoodmicro.2009.07.016.

Tanguler, H., and H. Erten. 2012. Occurrence and growth of lactic acid bacteria species during the fermentation of shalgam (salgam), a traditional Turkish fermented beverage. LWT - Food Science and Technology 46 (1):36-41. doi: 10.1016/j.lwt.2011.10.026.

Tanriseven, D., P. Kadiroglu, S. Selli, and H. Kelebek. 2020. LC-DADESI-MS/MS-assisted elucidation of the phenolic compounds in shalgams: Comparison of traditional and direct methods. Food Chemistry 305:125505. doi: 10.1016/j.foodchem.2019.125505.

Thakur, N., and T. Chand Bhalla 2004. Characterization of some traditional fermented foods and beverages of Himachal Pradesh. Indian Journal of Traditional Knowledge 3:325-335. http://nopr.niscair.res. in/bitstream/123456789/9365/1/IJTK\%283\%29325-335.pdf

Thakur, N., Savitri, P. E. J. Saris, and T. C. Bhalla. 2015. Microorganisms associated with amylolytic starters and traditional fermented alcoholic beverages of North Western Himalayas in India. Food Bioscience 11:92-6. doi: 10.1016/j.fbio.2015.05.002.

Todorov, S. D., M. Botes, C. Guigas, U. Schillinger, I. Wiid, M. B. Wachsman, W. H. Holzapfel, and L. M. Dicks. 2008. Boza, a natural source of probiotic lactic acid bacteria. Journal of Applied Microbiology 104 (2):465-77. doi: 10.1111/j.1365-2672.2007.03558.x.

Toktaş, B., F. Bildik, and B. Özçelik. 2018. Effect of fermentation on anthocyanin stability and in vitro bioaccessibility during shalgam (şalgam) beverage production. Journal of the Science of Food and Agriculture 98:3066-3075. 10.1002/jsfa.8806.

Topping, D. L., and P. M. Clifton. 2001. Short-chain fatty acids and human colonic function: Roles of resistant starch and nonstarch polysaccharides. Physiological Reviews 81 (3):1031-64. doi: 10.1152/ physrev.2001.81.3.1031.

Torres-Maravilla, E., M. Lenoir, L. Mayorga-Reyes, T. Allain, H. Sokol, P. Langella, M. E. Sánchez-Pardo, and L. G. Bermúdez-Humarán. 2016. Identification of novel anti-inflammatory probiotic strains isolated from pulque. Applied Microbiology and Biotechnology 100 (1): 385-96. doi: 10.1007/s00253-015-7049-4.

Turan, I., O. Dedeli, S. Bor, and T. Ilter. 2015. Effects of a Kefir supplement on symptoms, colonic transit, and bowel satisfaction score in patients with chronic constipation: A pilot study. The Turkish Journal of Gastroenterology 25 (6):650-6. doi: 10.5152/tjg.2014.6990.

Väkeväinen, K., J. Hernández, A.-I. Simontaival, P. Severiano-Pérez, G. Díaz-Ruiz, A. von Wright, C. Wacher-Rodarte, and C. Plumed-Ferrer. 2020. Effect of different starter cultures on the sensory properties and microbiological quality of Atole agrio, a fermented maize product. Food Control 109:106907. doi: 10.1016/j.foodcont.2019.106907.

Väkeväinen, K., A. Valderrama, J. Espinosa, D. Centurión, J. Rizo, D. Reyes-Duarte, G. Díaz-Ruiz, A. von Wright, P. Elizaquível, K. Esquivel, et al. 2018. Characterization of lactic acid bacteria recovered from atole agrio, a traditional Mexican fermented beverage. LWT 88:109-18. doi: 10.1016/j.lwt.2017.10.004.

Valderrama, A. 2012. Diversidad de bacterias lácticas del atole agrio de Villahermosa Tabasco, México. Universidad Nacional Autonoma de México https://doi.org/UnpublishedBacherloŕsthesis.

van Hylckama Vlieg, J. E. T., P. Veiga, C. Zhang, M. Derrien, and L. Zhao. 2011. Impact of microbial transformation of food on health from fermented foods to fermentation in the gastro-intestinal tract. Current Opinion in Biotechnology 22 (2):211-9. doi: 10.1016/j.copbio.2010.12.004.

Velićanski, A. S., D. D. Cvetković, V. T. Tumbas Šaponjac, J. J. Vulić, and J. J. Vulić. 2014. Antioxidant and antibacterial activity of the beverage obtained by fermentation of sweetened lemon balm (Melissa officinalis L.) Tea with symbiotic consortium of bacteria and yeasts. Food Technology and Biotechnology 52 (4):420-9. doi: 10.17113/ftb.52.04.14.3611.

Velu, V., A. Nagender, P. G. Prabhakara Rao, and D. G. Rao. 2006. Dry milling characteristics of microwave dried maize grains (Zea mays L.). Journal of Food Engineering 74 (1):30-6. doi: 10.1016/j. jfoodeng.2005.02.014.

Vieria-Dalodé, G., Y. E. Madodé, J. Hounhouigan, L. Jespersen and M. Jakobsen. 2008. Use of starter cultures of lactic acidbacteria and yeasts as inoculum enrichment for the production of Gowé, a sour beverage from Benin. African Journal of Microbiology Research 2 (7): 179-86.

Vijaya Kumar, B., S. V. N. Vijayendra, and O. V. S. Reddy. 2015. Trends in dairy and non-dairy probiotic products - A review. Journal of Food Science and Technology 52 (10):6112-24. doi: 10. 1007/s13197-015-1795-2.

Vilela, A. 2019. The importance of yeasts on fermentation quality and human health-promoting compounds. Fermentation 5 (2):46. doi: 10.3390/fermentation5020046.

Vu, B., M. Chen, R. J. Crawford, and E. P. Ivanova. 2009. Bacterial extracellular polysaccharides involved in biofilm formation. Molecules (Basel, Switzerland) 14 (7):2535-54. doi: 10.3390/ molecules 14072535 .

Wacher, C., A. Cañas, P. E. Cook, E. Barzana, and J. D. Owens. 1993. Sources of microorganisms in pozol, a traditional Mexican fermented maize dough. World Journal of Microbiology and Biotechnology 9 (2):269-74. doi: 10.1007/BF00327853.

Wacher, C., A. Cañas, E. Bárzana, P. Lappe, M. Ulloa, and J. D. Owens. 2000. Microbiology of Indian and Mestizo pozol fermentations. Food Microbiology 17 (3):251-6. doi: 10.1006/fmic.1999.0310.

Wang, C. T., B. P. Ji, B. Li, R. Nout, P. L. Li, H. Ji, and L. F. Chen. 2006. Purification and characterization of a fibrinolytic enzyme of Bacillus subtilis DC33, isolated from Chinese traditional Douchi. Journal of Industrial Microbiology \& Biotechnology 33 (9):750-8. doi: 10.1007/s10295-006-0111-6.

Watanabe, K., J. Fujimoto, Y. Tomii, M. Sasamoto, H. Makino, Y. Kudo, and S. Okada. 2009. Lactobacillus kisonensis sp. nov., Lactobacillus otakiensis sp. nov., Lactobacillus rapi sp. nov. and Lactobacillus sunkii sp. nov., heterofermentative species isolated from sunki, a traditional Japanese pickle. International Journal of Systematic and Evolutionary Microbiology 59 (Pt 4):754-60. doi: 10. 1099/ijs.0.004689-0.

Wood, B. J. B., and W. H. Holzapfel. 1995. The genera of lactic acid bacteria. Dordrecht: Springer.

Wu, J., W. Liao, and C. C. Udenigwe. 2017. Revisiting the mechanisms of ACE inhibitory peptides from food proteins. Trends in Food Science and Technology 69:214-219. 10.1016/j.tifs.2017.07.011. 
Wu, W., and H. Li 2018. Metabolites of lactic acid bacteria. In Lactic acid bacteria in foodborne hazards reduction, 87-113. Singapore: Springer. 10.1007/978-981-13-1559-6_4.

Yan, P. M., W. T. Xue, S. S. Tan, H. Zhang, and X. H. Chang. 2008. Effect of inoculating lactic acid bacteria starter cultures on the nitrite concentration of fermenting Chinese paocai. Food Control 19 (1):50-5. doi: 10.1016/j.foodcont.2007.02.008.

Yeo, S. K., and J. A. Ewe. 2015. Advances in fermented foods and beverage. Elsevier: Amsterdam.

Yonzan, H., and J. P. Tamang. 2010. Microbiology and nutritional value of Selroti, an ethnic fermented cereal food of the Himalayas. Food Biotechnology 24 (3):227-47. doi: 10.1080/08905436.2010.507133.
Yonzan, H., and J. P. Tamang. 2013. Optimization of traditional processing of Selroti, a popular cereal-based fermented food. Journal of Scientific \& Industrial Research 72:43-47.

Yousif, N. M. K., M. Huch, T. Schuster, G. S. Cho, H. A. Dirar, W. H. Holzapfel, and C. M. A. P. Franz. 2010. Diversity of lactic acid bacteria from Hussuwa, a traditional African fermented sorghum food. Food Microbiology 27 (6):757-68. doi: 10.1016/j.fm. 2010.03.012.

Yunita, D., and C. E. R. Dodd. 2018. Microbial community dynamics of a blue-veined raw milk cheese from the United Kingdom. Journal of Dairy Science 101 (6):4923-35. doi: 10.3168/jds. 2017-14104. 